\title{
Alina Sultanova
}

\section{SIGNIFICANCE OF BETA-HERPESVIRUSES (HHV-6, HHV-7) INFECTION UNDER THE CONDITIONS OF IMMUNE DISORDERS}

Summary of the Doctoral Thesis for obtaining the degree of a Doctor of Medicine Speciality - Virology

Riga, 2014 


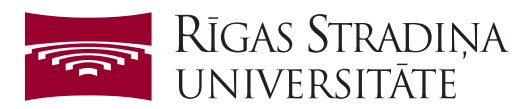

Alina Sultanova

\section{SIGNIFICANCE OF BETA-HERPESVIRUSES (HHV-6, HHV-7) INFECTION UNDER THE CONDITIONS OF IMMUNE DISORDERS}

Summary of the Doctoral Thesis
for obtaining the degree of a Doctor of Medicine

Speciality - Virology

Riga, 2014 
This work has been carried out at Rīga Stradiņš University (RSU) August Kirchenstein Institute of Microbiology and Virology in collaboration with Pauls Stradins Clinical University Hospital (Latvian Transplantation Center), Riga East Clinical University Hospital (Latvian Oncology Center and Clinic "Gaiļezers") and Riga $1^{\text {st }}$ Hospital.

Scientific supervisors:

Dr. med. Associate Professor Modra Murovska, RSU August Kirchenstein Institute of Microbiology and Virology, Latvia

Dr. habil. biol. Senior Researcher Svetlana Chapenko, RSU August Kirchenstein Institute of Microbiology and Virology, Latvia

Official reviewers:

Dr. med. Professor Inara Logina, Rīga Stradinš̌ University, Latvia Dr. habil. med. Professor Aija Zilevica, Faculty of Medicine, University of Latvia

Dr. biol. sci. Mykolas Mauricas, State Research Institute Centre for Innovative Medicine, Lithuania

Doctoral Thesis will be defended on $3^{\text {rd }}$ of June 2014, at 15.00 during Rīga Stradinš̌ University Promotional Council of Medicine meeting in 16 Dzirciema Street, in the Lecture theatre Hippocrates.

Doctoral Thesis is available at the library of Rīga Stradinšs University and on the home page: www.rsu.lv

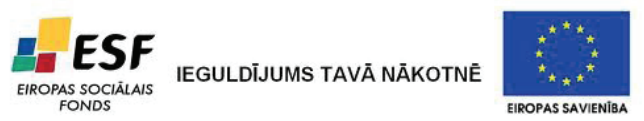

Doctoral Thesis was supported by ESF project "Support for doctoral study programs and research degrees RSU" 2009/0147/1DP/1.1.2.1.2/09/IPIA/VIAA/009

Secretary of the Promotional Council:

Dr. med. Associate Professor Angelika Krumina 


\section{TABLE OF CONTENTS}

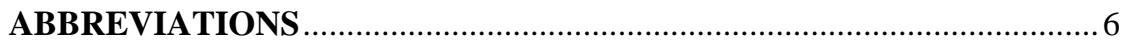

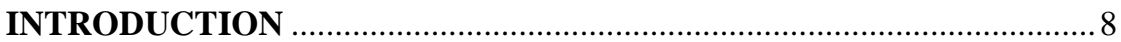

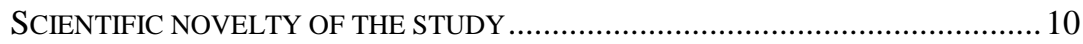

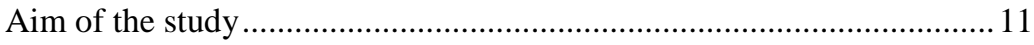

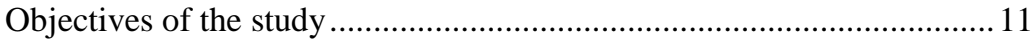

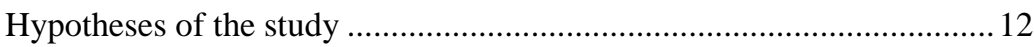

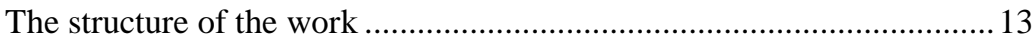

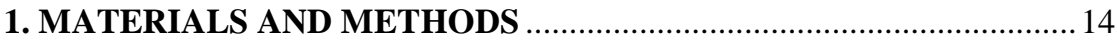

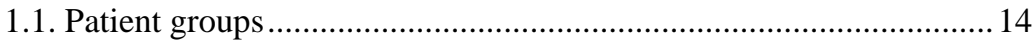

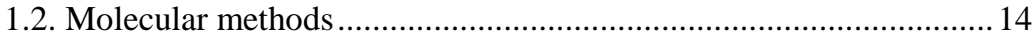

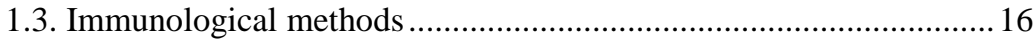

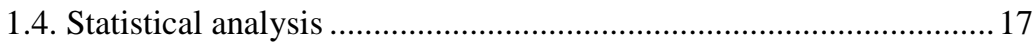

2. RESULTS

2.1. INVOLVEMENT OF HHV-6 AND HHV-7 INFECTION IN THE

DEVELOPMENT OF POST-TRANSPLANT COMPLICATIONS ................................. 19

2.1.1. Presence of HHV-6 and HHV-7 infection markers

in renal transplant recipients

2.1.2. Analysis of immunocompetent cell populations

in renal transplant recipients dependently on lymphocytes'

count

2.1.3. Presence of HHV-6 and HHV-7 infection in renal

transplant recipients with and without lymphopenia .22 
2.1.4. Comparative analysis of immunocompetent cell populations in renal transplant recipients without and with lymphopenia dependently on beta-herpesviruses infection 24

2.1.5. Complications development in renal transplant recipients 24

2.2. INVOLVEMENT OF HHV-6 AND HHV-7 INFECTION IN THE

CLINICAL COURSE OF GASTROINTESTINAL CANCER (GIC) 25

2.2.1. Presence of HHV-6 and HHV-7 infection in patients with GIC 25

2.2.2. Analysis of immunocompetent cell populations in patients with GIC dependently on lymphocytes' count 27 2.2.3. Presence of HHV-6 and HHV-7 infection in GIC patients with and without lymphopenia 28 2.2.4. Comparative analysis of immunocompetent cell populations in GIC patients without and with lymphopenia dependently on beta-herpesviruses infection 2.2.5. Pro-inflammatory cytokines levels in GIC patients with and without lymphopenia 30

2.2.6. Gastrointestinal cancer clinical outcomes dependently on beta-herpesviruses infection 32

2.3. INVOLVEMENT OF HHV-6 AND HHV-7 INFECTION IN THE

DEVELOPMENT OF AUTOIMMUNE THYROID DISEASES (AIT)

2.3.1. Presence of HHV-6 and HHV-7 infection in patients with AIT 33

2.3.2. Analysis of immunocompetent cell populations in patients with AIT dependently on viral infection 34 2.3.3. Presence of HHV-6 and HHV-7 infection in thyroid gland tissue 35 
2.3.4. Comparison of HHV-6 infection presence

in thyroid gland tissue and blood samples............................................... 36

2.3.5. HHV-6 load in blood and tissue DNA …...................................... 37

2.4. COMPARATIVE ANALYSIS BETWEEN PATIENTS

WITH DIFFERENT IMMUNE SYSTEM DYSFUNCTIONS .......................................39

2.4.1. Comparison of beta-herpesviruses infection frequency .................39

2.4.2. Comparison of immunocompetent cell populations

dependently on beta-herpesviruses infection............................................ 41

3. DISCUSSION

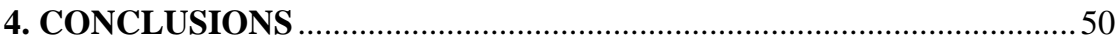

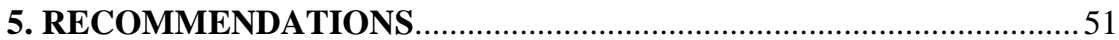

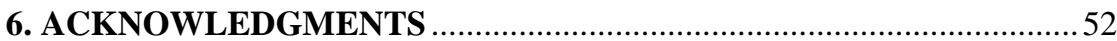

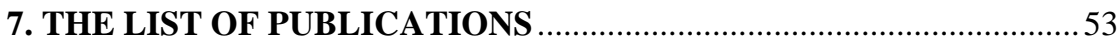

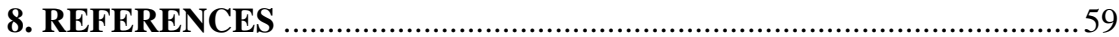




\section{ABBREVIATIONS}

AIDS - acquired immunodeficiency syndrome

AIT - autoimmune thyroiditis

AITD - autoimmune thyroid disease

$\mathrm{CI}$ - confidence interval

CMV - cytomegalovirus

DNA - deoxyribonucleic acid

ELISA - enzyme-linked immunosorbent assay

FACS - fluorescence-activated cell sorting

GIC - gastrointestinal cancer

GVHD - graft versus host disease

HHV-6 - human herpesvirus 6

HHV-7 - human herpesvirus 7

IFA - indirect fluorescent antibody test

IgG - immunoglobulin $\mathrm{G}$

$\operatorname{IgM}$ - immunoglobulin $\mathrm{M}$

IL-1 $\beta$ - interleukin-1 beta

IL-2 - interleukin-2

IL-6 - interleukin-6

Leu - leukocytes

Ly - lymphocytes

Mo - monocytes

$\mathrm{NK}$ - natural killers

nPCR - nested polymerase chain reaction

$\mathrm{OR}$ - odds ratio 
$\mathrm{P}-\mathrm{p}$ value

PBMC - peripheral blood mononuclear cells

PCR - polymerase chain reaction

TG- thyroglobulin

TNF- $\alpha$ - tumour necrosis factor

TPO- thyroid peroxidase

TSH- thyroid-stimulating hormone 


\section{INTRODUCTION}

Today the majority of chronic diseases are already quite strongly associated with infectious agents, including viruses. In most of cases these are viruses that cause persistent infection and who themselves possess the ability to affect the body's immune system. Recently, these immunomodulating viruses have been receiving increasing attention, which is determined by several factors:

- these viruses are widely distributed after primary infection and they exist in a persistent form throughout life;

- they can be activated by immunosuppressant factors;

- they by themselves possess immunosuppressant properties and they can change the body's immune status;

- they often cause serious complications in cases of an immunosuppression caused by medication after solid organ and stem cell transplantation;

- they cause a variety of complications in patients with immunosuppressive background caused by underlying disease, for an example in oncology patients;

- they can initiate chronic inflammatory processes that can lead to autoimmune pathology, and neoplastic changes;

- in the case of co-infection they can activate each other (Sprengers and Janssen, 2005; Mocarski Jr, 2002; Lucas and McFadden, 2004).

The immunomodulating viruses mentioned above include lymphotropic herpesviruses - human herpesvirus -6 and -7 (HHV-6 and HHV-7), that belong to Betaherpesvirinae subfamily Roseolovirus genus. 
HHV-6 was isolated in 1986 from the interleukin-2 (IL-2)-stimulated peripheral blood mononuclear cells obtained from the AIDS patients and patients with lymphoproliferative diseases. HHV-6 was described in two variants and later as a two species - HHV-6A and HHV-6B.

Since the moment of discovery, HHV-6 has been associated with a wide range of clinical conditions and chronic diseases, due to high ubiquitous nature of this virus. Separation of HHV-6 into two distinguished species (HHV-6A and HHV-6B) only added questions concerning involvement of this virus infection in etiopathogenesis of various diseases. HHV-6A is frequently found in multiple sclerosis (MS), chronic fatigue syndrome (CFS), acquired immunodeficiency syndrome (AIDS) and cancer patients. HHV-6B causes Roseola infantum, febrile illness and encephalitis in infants and it reactivates in transplant patients, causing complications such as encephalitis, pneumonia and liver damage. In renal transplant patients, HHV-6 has been associated with the development of chronic allograft nephropathy (Chapenko et al., 2009) and graft versus host disease (GVHD) (Caiola et al., 2012). For a long time only HHV-6B was associated with the development of complications in renal transplant patients, due to it's detection particularly in the mononuclear cells of renal transplants (Helantera et al., 2008), and HHV-6B is also frequently found in the gastrointestinal tract of these patients (Lempinen et al., 2012). However, in recent study the predominance of HHV-6A viremia is reported in the plasma/serum among cohort of renal transplant patients (Csoma et al., 2011).

Data about HHV-6 implication in different cancer diseases is controversial. While a lot of researches associate HHV-6 (especially HHV-6B) with the nodular sclerosis subtype of Hodgkin's lymphoma (Lacroix et al., 2010; Siddon et al., 2012) and leukaemia (Ogata et al., 2011), there are lack of studies on HHV-6 implication in solid tumour development. However, several 
investigators have suggested that HHV-6 possess an oncogenic potential. Cells transfected with HHV-6 can cause tumours in nude mice (Puri et al., 1991).

Recent studies have proposed a certain role for HHV-6 in several autoimmune disorders, including autoimmune acute hepatitis (Grima et al., 2008) and autoimmune hemolytic anemia/neutropenia (Yagasaki et al., 2010). The study of 2012 ${ }^{\text {th }}$ has linked HHV-6A to Hashimoto's thyroiditis (Caselli et al., 2012). However, additional evidence is required, especially taking into account the distribution of HHV-6A and HHV-6B.

HHV-7 clinical role is poorly documented, but it is possibly associated with the development of Pityriasis rosea (Black et al., 1999; Rebora et al., 2010) and it could act as HHV-6 activator and CMV co-factor in complication development in post-transplant patients (Chapenko et al., 2001; Chan et al., 2004; Holden and Vas, 2007; Zawilinska et al., 2011).

In this work a relation of HHV-6 and HHV-7 infection with different chronic diseases and complications development was investigated, to acquire lacking data on involvement of theses viruses in the development of immune system dysfunction. Secondary, the distribution of HHV-6A and HHV-6B infection among different patient-groups in Latvia was ascertained.

\section{Scientific novelty of the study}

- It is the first time when HHV-6 and HHV-7 infection reactivation frequency is compared in three groups of patients with different causes of immune system dysfunction (immunosuppressive therapy, underlying disease and autoimmune process); 
- The higher risk of lymphopenia development in patients with gastrointestinal cancer during active HHV-6 and HHV-7 infection is proved and statistically confirmed.

- Strong association between beta-herpesviruses HHV-6 and HHV-7 infection and autoimmune thyroiditis is discovered.

- Comparative analysis of changes in immunocompetent cell populations and severity of immunosuppression among three different patients' groups are carried out.

\section{Aim of the study}

The aim of the present study was to ascertain the involvement of betaherpesviruses infection in the pathogenesis and clinical course of chronic diseases and development of post-transplant complications due the ability to change host-pathogen interaction.

\section{Objectives of the study}

1. Create the groups of patients with immune system dysfunctions caused by different factors:

a. Renal transplant recipients with immunosuppression caused by immunosuppressive therapy;

b. Gastrointestinal cancer patients with immunosuppression caused by underlying disease;

c. Patients with autoimmune thyroiditis. 
2. Explore the presence and activity phase of beta-herpesviruses HHV-6 and HHV-7 infection in patients with immune system dysfunction caused by different factors.

3. Examine the cellular immunity in renal transplant recipients, patients with underlying disease (gastrointestinal cancer) and patients with autoimmune process (autoimmune thyroiditis).

4. Clarify the association between beta-herpesviruses HHV-6 and HHV7 infection and post-transplant complications development, chronic disease clinical course and autoimmune process.

5. Build the database of patients, including clinical and laboratory data.

\section{Hypothesis of the study}

1. Reactivation of HHV-6 and HHV-7 infection is occurring more often in patients with immune system dysfunctions than in control group individuals.

2. HHV-6 and HHV-7 reactivation leads to more severe imbalance of the immune system.

3. Higher viral load in thyroid tissue than in peripheral blood indicates that thyroid gland is a possible place of HHV-6 latency which could be a cause of autoimmune process development. 


\section{The structure of the work}

The doctoral thesis is written in English. It consists of the following parts: introduction, scientific novelty, the aim, objectives, hypothesis, literature review, materials and methods, results, discussion, conclusion and recommendations. The work is written on 124 pages with 23 Tables and 21 Figures. 209 citations of literature are included in the reference list. The results of the

work are published in 9 papers (in pre-reviewed editions) and presented at 17 local/international conferences/congresses. 


\section{MATERIALS AND METHODS}

\subsection{Patient groups}

Three patient groups - patients with immunosuppressive drug treatment (renal transplant recipients; $n=47-27$ men and 20 women - mean age 49; from 28 to 78 years); patients with immune system disorders related to the underlying disease (patients with gastrointestinal cancer; $n=65-42$ women and 23 men - mean age 54; from 39 to 85 years) and patients with autoimmune disorders (autoimmune thyroiditis; $\mathrm{n}=44-43$ women and one man - mean age 45; from 25 to 78 years) were included in the study.

Practically healthy blood donors were included as control group ( $\mathrm{n}=150-77$ females and 73 males - mean age 37; from 18 to 65 years). Postmortem thyroid gland samples without any pathological macro or micro changes were used as the tissue controls in investigation of operated thyroid glands of patients with autoimmune thyroiditis $(n=41-11$ were women and 30 men - mean age 52; from 41 to 78 years). The research was established with the approval of the Ethics Committee of the Rīga Stradiņš University.

\subsection{Molecular methods}

Isolation of DNA from peripheral whole blood and tissue samples: All whole blood and thyroid gland tissue DNA was extracted using phenolchloroform method. 
Isolation of DNA from plasma samples: The QIAamp Blood Kit (QIAGEN, Hilden, Germany) was used to purify DNA from cell-free blood plasma following manufacturer's protocol. Before DNA purification the plasma samples were treated with DNase I (Fermentas, Vilnius, Lithuania).

DNA quality and quantity control: According to the manufacturer's instructions $2 \mu \mathrm{l}$ of DNA solution was taken and concentration measured using spectrophotometer NanoDrop 1000 at a wavelength of 260, resulting in the concentration of each sample, which is expressed in the unit of measurement $\mathrm{ng} / \mu \mathrm{l}$. The sample purity control was done by using the $260 / 280$ ratio diapason, which must be no less than 1.8 .

Beta $(\beta)$-globin PCR with appropriate primers was used (Vanndame et al., 1995) to determine the quality of DNA isolated from blood and tissue, and to exclude plasma DNA contamination by cell debris DNA.

Nested Polymerase Chain Reaction (nPCR): The technique of nPCR was used to detect viral genomic sequences in DNA isolated from whole blood and cell free plasma (markers of persistent and active phase of persistent infection, respectively). PCR amplification of viral DNA was carried out in the presence of $1 \mu \mathrm{g}$ of whole blood DNA or $10 \mu \mathrm{l}$ of plasma DNA (which corresponded to $200 \mu \mathrm{l}$ of plasma). HHV-6 and HHV-7 were detected in accordance with Secchiero et al. 1995 and Berneman et al. 1992, respectively. Positive controls (HHV-6 and HHV-7 genomic DNA; Advanced Biotechnologies Inc, Columbia, MD, USA and negative controls (DNA obtained from practically healthy HHV-6 and HHV-7 negative blood donor and no template DNA) were included in each experiment.

Determination of HHV-6 A and HHV-6B by nPCR and Hind III restriction: Determination of $\mathrm{HHV}-6 \mathrm{~A}$ and $\mathrm{HHV}-6 \mathrm{~B}$ was made in correspondence to Lyall and Cubie, 1995. Expected PCR product length was: 
163bp after the marker pUC 19 DNA / MspI (Hpa2) Marker23 (MBI Fermantes Lithuania)], the results were visualized and processed with BioSpectrum 610 MultiSpectral Imaging System, USA.

Quantitative Real-time PCR: The viral load of HHV-6 in whole blood and tissue DNA samples from patients with HHV-6 persistent infection was determined using the HHV-6 Real-Time Alert Q-PCR kit (Nanogen Advanced Diagnostics, Buttigliera Alta, Italy) and an Applied Biosystems 7500 Real-time PCR System (Applied Biosystems, Carlsbad, CA, USA), in accordance with the manufacturer's recommendations. Collected data were processed and analyzed with specialized software ABI 7500 system. The data are calculated to get the viral copies $/ 10^{6}$ cells.

\subsection{Immunological methods}

Viral specific antibody detection: For the approval of obtained PCR results, determination of the HHV-6-specific IgG class antibodies in plasma was carried out using commercial ELISA kit (Panbio, Sinnamon Park, QLD, Australia). To determine the presence of HHV-7-specific IgG class antibodies in plasma samples IFA work set (EUROIMMUN, Germany) was used following the manufacturer's developed protocol. Preparations were analyzed with immunofluorescence microscope "Nikon Eclipse 80i" at 400× magnification and the visualization program "Lucia Image Analysis Systems" Lucia 5.0 version.

Auto-antibody detection: Commercial ELISA kits (EUROIMMUN, Germany) were used to determine the presence of auto-antibodies against to 
thyroid peroxidase (TPO), against to thyroglobulin (Tg) and thyroid stimulating hormone (TSH) receptor.

Assay for cytokine determination: ELISA kits (Pierce Biotechnology, Rockford, IL, USA, and AviBion, Helsinki, Finland) were used to detect the levels of tumor necrosis factor (TNF)- $\alpha$, interleukin (IL)-1 $\beta$ and IL-6 in plasma. The sensitivity of the ELISAs were $<3 \mathrm{pg} / \mathrm{ml}$ for IL- $1 \beta$ and $<2 \mathrm{pg} / \mathrm{ml}$ for TNF- $\alpha$ and IL-6. In addition, the expression level of soluble IL-2 receptor (sIL-2R) was measured using a solid-phase competitive chemi-luminescent enzyme immunoassay (CLIA; Siemens, Los Angeles, CA, USA) in accordance with the manufacturer's recommendations. The assay was able to detect $5 \mathrm{U} / \mathrm{ml}$. All samples were tested in duplicate.

FACS analysis and sorting: BD FACSAria II flow cytometer (USA) and BD FACSDiva software were used for sorting and analysing of peripheral blood mononuclear cells (PBMC). Commercial monoclonal antibodies conjugated with different flourochromes (anti-CD3-FITC, CD4-PerCP-Cy7, CD8-PE, CD16-V450, CD19-APC, CD45-V500, CD56-V450 and CD95PerCP-Cy 5.5) were used to distinguish and sort main lymphocyte populations.

\subsection{Statistical analysis}

All calculations were performed with the MedCalc Software version 12.3 (Ostend, Belgium). Statistical differences in the prevalence of latent and active HHV-6 and HHV-7 infection were assessed by Fisher's exact test. Plasma levels of cytokines were expressed as the mean \pm SD. Immunological parameters were analyzed using t-test. Regression analysis was used to assess 
the continuous variable values; a value of $\mathrm{p}<0.05$ was considered to be significant. 


\section{RESULTS}

\subsection{Involvement of HHV-6 and HHV-7 infection in the development of post-transplant complications}

\subsubsection{Presence of HHV-6 and HHV-7 infection markers in renal transplant recipients}

Persistent beta-herpesviruses infection was detected in 42 out of $47(89 \%)$ renal transplant recipients. HHV-6 persistent infection was found in 15 out of $47(32 \%)$ recipients, HHV-7 persistent infection - in 40 out of $47(85 \%)$ recipients, that is statistically higher $(\mathrm{p}=0.02)$ than in healthy blood donors - 101 out of 150 (67\%). Persistent single HHV-6 infection was found in two out of 47 recipients; however, single HHV-7 infection was detected in 27 out of 47 recipients and persistent HHV-6 + HHV-7 infection - in 13 out of 47 individuals.

Latent single HHV-6 infection was detected in one out of two, HHV-7 latent infection in 16 out of 27 (59\%) and HHV-6 + HHV-7 latent infection in 5 out of $13(39 \%)$ renal transplant recipients. Activation rate was higher in patients with double HHV-6 + HHV-7 infection -8 out of $13(62 \%)$ than in recipients with single HHV-6 infection - one out of two (50\%) or HHV-7 infection - 11 out of 27 (41\%). In all HHV-6 positive samples HHV-6B was defined. There was no significant difference in the presence of latent HHV-6 infection between recipients and healthy individuals. However, HHV-7 latent 
infection was significantly higher $(\mathrm{p}=0.006)$ in healthy blood donors $(85 \%)$ than in renal transplant recipients $(59 \%)$.

HHV-6 and double HHV-6 + HHV-7 active infection was found only in renal transplant recipients (one out of two and 8 out of 13 , respectively). Rate of active HHV-7 infection was significantly higher $(\mathrm{p}=0.006)$ in renal transplant recipients $11 / 27(41 \%)$ than healthy blood donors $12 / 83(14 \%)$ (Table 2.1).

Although, HHV-6 genomic sequence was detected in 15/47 (32\%) of renal transplant recipients, presence of anti- HHV-6 specific IgG class antibodies was detected in 36/47 (77\%) of patients.

Table 2.1.

\section{Presence of beta-herpesviruses infection in renal transplant recipients and} healthy blood donors

\begin{tabular}{|l|c|c|c|c|}
\hline & $\begin{array}{c}\text { HHV-6 } \\
\text { persistent } \\
\text { (latent/active) } \\
\text { infection }\end{array}$ & $\begin{array}{c}\text { HHV-7 } \\
\text { persistent } \\
\text { (latent/active) } \\
\text { infection }\end{array}$ & $\begin{array}{c}\text { HHV-6 + HHV- } \\
7 \text { persistent } \\
\text { (latent/active) } \\
\text { infection }\end{array}$ & $\begin{array}{c}\text { Without } \\
\text { HHV-6 or } \\
\text { HHV-7 } \\
\text { infection }\end{array}$ \\
\hline $\begin{array}{l}\text { Renal transplant } \\
\text { recipients (n=47) }\end{array}$ & $2(4.3 \%)$ & $27(57 \%)$ & $13(27.6 \%)$ & 5 \\
$(1 / 1)$ & $(16 / 11)$ & $(5 / 8)$ & $(11 \%)$ \\
\hline $\begin{array}{l}\text { Blood donors } \\
(\mathrm{n}=150)\end{array}$ & $13(8.6 \%)$ & $83(55 \%)$ & $30(20 \%)$ & 24 \\
& $(13 / 0)$ & $(71 / 12)$ & $(30 / 0)$ & $(16 \%)$ \\
\hline
\end{tabular}




\subsubsection{Analysis of immunocompetent cell populations in renal transplant recipients dependently on lymphocytes' count}

It was possible to divide renal transplant recipients into two groups according to the lymphocyte count: group I $(\mathrm{n}=17)$ - patients without lymphopenia (lymphocytes $>1400$ cells in $1 \mathrm{~mm}^{3}$ of peripheral blood) and group II $(n=30)$ - patients with lymphopenia (lymphocytes < 1400 cells in $1 \mathrm{~mm}^{3}$ of peripheral blood). The mean absolute number of lymphocytes in the group I was two times (50\%) higher than in the group II $-1890 \pm 440 \times 10^{6} / \mathrm{L}$ and $850 \pm 410 \times 10^{6} / \mathrm{L}$, respectively. Comparative analyses of the lymphocyte subsets between the group I and II $\left(\mathrm{CD}^{+}, \mathrm{CD}^{+}, \mathrm{CD} 8^{+}, \mathrm{CD} 38^{+}, \mathrm{CD} 16^{+}\right.$, $\mathrm{CD} 19^{+}, \mathrm{CD} 25^{+}$and $\mathrm{CD} 95^{+}$) showed significant decrease of Ly subsets in the group II - approximately two fold decrease in comparison with the group I (Table 2.2). 
Table 2.2.

Absolute counts of immunocompetent cells populations in the renal transplant recipients' groups I and II

\begin{tabular}{|c|c|c|c|c|c|}
\hline \multirow[b]{2}{*}{ Parameters } & \multicolumn{2}{|c|}{ Group I Ly > $1400(n=17)$} & \multicolumn{2}{|c|}{ Group II Ly < $1400(n=30)$} & \multirow[b]{2}{*}{$\mathrm{p} \leq 0.05$} \\
\hline & $\begin{array}{c}\text { Absolute count } \\
\pm \text { SD }\end{array}$ & $\begin{array}{c}\text { Count } \\
\%\end{array}$ & $\begin{array}{c}\text { Absolute count } \\
\pm \mathrm{SD}\end{array}$ & $\begin{array}{c}\text { Count } \\
\%\end{array}$ & \\
\hline Leu & $8450 \pm 2490$ & & $6950 \pm 2370$ & & 0.04 \\
\hline Ly & $1890 \pm 440$ & 24.92 & $850 \pm 410$ & 12.57 & $<0.0001$ \\
\hline $\mathrm{CD}^{+}$ & $1510 \pm 390$ & 80.12 & $620 \pm 400$ & 67.43 & $<0.0001$ \\
\hline $\mathrm{CD}^{+}$ & $630 \pm 300$ & 40.53 & $230 \pm 190$ & 31.43 & $<0.0001$ \\
\hline $\mathrm{CD}^{+}$ & $580 \pm 210$ & 38.35 & $220 \pm 200$ & 32.03 & $<0.0001$ \\
\hline $\mathrm{CD} 8^{+}$ & $520 \pm 350$ & 26.18 & $270 \pm 170$ & 31.77 & 0.002 \\
\hline $\mathrm{CD} 16^{+}$ & $150 \pm 70$ & 10.00 & $90 \pm 50$ & 17.23 & 0.001 \\
\hline $\mathrm{CD} 19^{+}$ & $130 \pm 60$ & 7.00 & $70 \pm 50$ & 9.50 & 0.0006 \\
\hline $\mathrm{CD}{ }^{+}$ & $850 \pm 440$ & 43.71 & $400 \pm 270$ & 44.83 & 0.0001 \\
\hline $\mathrm{CD}^{2} 5^{+}$ & $80 \pm 40$ & 4.29 & $30 \pm 30$ & 3.10 & $<0.0001$ \\
\hline $\mathrm{CD}^{+} / \mathrm{CD}^{+}{ }^{+}$ & $1.24 \pm 0.70$ & & $1.18 \pm 0.70$ & & \\
\hline
\end{tabular}

\subsubsection{Presence of HHV-6 and HHV-7 infection in renal transplant recipients with and without lymphopenia}

HHV-6 persistent infection was found in 8 out of 17 (47\%) group I patients and in 7 out of 30 (23\%) patients of the group II. However, HHV-7 persistent infection was presented in 15 out of 17 (88\%) group I patients and in 25 out of $30(83 \%)$ patients of the group II. Presence of single HHV-6 persistent infection was detected only in 2 out of $30(6.6 \%)$ patients with lymphopenia. Higher presence of single HHV-7 persistent infection was found in the group II of patients in comparison to the group I (66\% and $41 \%$, respectively). However, higher presence of double HHV-6 + HHV-7 persistent infection was detected in 8 out of 17 (47\%) renal transplant recipients without 
lymphopenia comparing to the group II patients with lymphopenia (5/30, $17 \%)$.

Single HHV-6 latent infection was revealed only in one patient from the group II (with lymphopenia); however, frequency of single HHV-7 latent infection between both groups showed no significant difference $(57 \%$ in the group I and $60 \%$ in the group II, respectively).

Double HHV-6 + HHV-7 latent infection was more prevalent in the group I patients (50\%) comparing with the group II patients (20\%).

Presence of single HHV-6 active infection was found only in one renal transplant recipient with lymphopenia, however, activation rate of single HHV-7 active infection showed no significant difference between both groups (43\% in the group I and $40 \%$ in the group II, respectively). Activation rate of double HHV-6 + HHV-7 active infection was more frequent in patients from the group II (80\%) than from the group I (50\%) (Table 2.3).

Table 2.3.

Presence of beta-herpesviruses (HHV-6 and HHV-7) infection in the group

I and II

\begin{tabular}{|c|c|c|c|c|}
\hline Patients & $\begin{array}{c}\text { HHV-6 } \\
\text { persistent } \\
\text { (latent/active) } \\
\text { infection }\end{array}$ & $\begin{array}{c}\text { HHV-7 } \\
\text { persistent } \\
\text { (latent/active) } \\
\text { infection }\end{array}$ & $\begin{array}{c}\text { HHV-6 + HHV- } \\
7 \text { persistent } \\
\text { (latent/active) } \\
\text { infection }\end{array}$ & $\begin{array}{c}\text { Without HHV-6 } \\
\text { or HHV-7 } \\
\text { infection }\end{array}$ \\
\hline $\begin{array}{c}\text { Group I } \\
(\mathrm{n}=17)\end{array}$ & $0(0 \%)$ & $7(41 \%)$ & $8(47 \%)$ & $2(12 \%)$ \\
$(4 / 3)$ & $20(66 \%)$ & $5(17 \%)$ & $3(10 \%)$ \\
\hline $\begin{array}{c}\text { Group II } \\
(\mathrm{n}=30)\end{array}$ & $2(6.6 \%)$ & $(12 / 8)$ & $(1 / 4)$ & \\
\hline
\end{tabular}




\subsubsection{Comparative analysis of immunocompetent cell populations in renal transplant recipients without and with lymphopenia dependently on beta-herpesviruses infection}

Comparative analysis of lymphocytes (Ly) subpopulations in the group I and II was performed dependently on beta-herpesviruses infection. Each group was subdivided into three subgroups: renal transplant recipients without infection, with latent and with active HHV-6 and/or HHV-7 infection. Both groups' patients with latent viral infection had tendency to increase in all populations (lymphocytes, $\mathrm{CD} 3^{+}, \mathrm{CD}^{+}, \mathrm{CD}^{+}, \mathrm{CD} 38^{+}, \mathrm{CD} 16^{+}, \mathrm{CD} 19^{+}, \mathrm{CD} 25^{+}$ and $\mathrm{CD}^{+} / \mathrm{CD}^{+}$ratio) comparing with the subgroups without HHV-6 and HHV-7 infection and with active viral infection. The most severe decrease of immunocompetent cells populations was detected in the group II patients with active beta-herpesviruses infection, especially in lymphocytes absolute count and $\mathrm{CD} 38^{+}$cells (to $21 \%$ and to $56 \%$, respectively), comparing to the group with latent viral infection.

Although, the group II patients with active HHV-6 or HHV-7 had significantly higher decrease $(\mathrm{p}=0.001)$ in $\mathrm{CD} 38^{+}$subpopulation (to $56 \%$ ) comparing to group with latent viral infection, the group I patients with active viral infection had significant $\left(\mathrm{p}=0.0001\right.$ ) downfall in $\mathrm{CD} 8^{+}$subpopulation (to

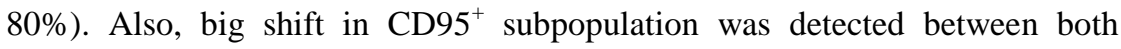
groups with latent and active viral infection.

\subsubsection{Complications development in renal transplant recipients}

Development of complications was found in 14 out of 47 (30\%) renal transplant recipients. Five patients had acute rejection (AR), four patients were 
with microbial infections and others had melanoma, sepsis, CMV disease, chronic allograft nephropathy (CAN) and acute hepatitis of non-identified etiology.

Analysis of patients with complications and beta-herpesviruses infection revealed that 10 out of $14(71 \%)$ renal transplant recipients with complications were with active HHV-6 or/and HHV-7 infection and only 4 out of 14 (29\%) with latent infection. The logistic regression analysis also showed that patients with active viral infection have higher risk of complication development (OR 4.5 ; $95 \%$ CI $1.12-18.13 ; \mathrm{p}=0.03$ ) than the patients with latent viral infection (OR 0.22; 95\% CI 0.06-0.89; $\mathrm{p}=0.03$ ).

\subsection{Involvement of HHV-6 and HHV-7 infection in the clinical course of gastrointestinal cancer (GIC)}

\subsubsection{Presence of HHV-6 and HHV-7 infection in patients with GIC}

HHV-6 and HHV-7 persistent infection was detected in 44 out of 65 (68\%) patients with GIC. In contrast, presence of HHV-6 and HHV-7 persistent infection was higher in healthy donors, where 126 out of 150 (84\%) individuals had persistent viral infection $(\mathrm{p}=0.01)$. In total HHV-6 persistent infection was detected in 16 out of $65(25 \%)$ patients and HHV-7 infection in 41 out of 65 (63\%) patients with GIC, which coincides with frequency in healthy blood donors (43 out of 150; $29 \%$ and 101 out of $150 ; 67 \%$, respectively). Presence of a single HHV-6 and HHV-7 persistent infection was more frequent in healthy donors than in GIC patients (9\%; 55\% and 4.6\%; 43\%, respectively). However, 
patients with GIC and healthy donors had the same level of persistent double HHV-6 + HHV-7 infection frequency.

Presence rate of single HHV-6, HHV-7 and double HHV-6 + HHV-7 latent infection was higher in healthy blood donors than in patients with GIC.

However, single HHV-6 active infection was found only in patients with GIC (one of two; 50\%). Activation rate of single HHV-7 infection was 15\% in healthy blood donors, in contrast to $25 \%$ in patients with GIC. Presence of double active viral infection was found only in 6 out of 7 (46\%) patients with GIC (Table 2.4).

Although, HHV-6 genomic sequence was detected in 16 out of $65(25 \%)$ of patients with GIC, anti- HHV-6 specific IgG class antibodies were found in 33 out of $65(51 \%)$ patients. HHV-7 genomic sequence was detected in $63 \%$ of patients by nPCR, however, presence of HHV-7 specific IgG class antibodies was detected in $75 \%$.

In all HHV-6 positive GIC patients HHV-6B was detected.

Table 2.4.

Presence of beta-herpesviruses infection in patients with GIC

\begin{tabular}{|l|c|c|c|c|}
\hline & $\begin{array}{c}\text { HHV-6 } \\
\text { persistent } \\
\text { (latent/ } \\
\text { active) } \\
\text { infection }\end{array}$ & $\begin{array}{c}\text { HHV-7 } \\
\text { persistent } \\
\text { (latent/active) } \\
\text { infection }\end{array}$ & $\begin{array}{c}\text { HHV-6 + HHV-7 } \\
\text { persistent } \\
\text { (latent/active) } \\
\text { infection }\end{array}$ & $\begin{array}{c}\text { Without } \\
\text { HHV-6 or } \\
\text { HHV-7 } \\
\text { infection }\end{array}$ \\
\hline $\begin{array}{l}\text { Patients with } \\
\text { gastrointestinal } \\
\text { cancer (n=65) }\end{array}$ & $\begin{array}{c}3(4.6 \%) \\
(2 / 1)\end{array}$ & $\begin{array}{c}28(43 \%) \\
(21 / 7)\end{array}$ & $\begin{array}{c}13(20 \%) \\
(7 / 6)\end{array}$ & $21(32 \%)$ \\
\hline $\begin{array}{l}\text { Blood donors } \\
(\mathrm{n}=150)\end{array}$ & $13(8.6 \%)$ & $83(55 \%)$ & $30(20 \%)$ & $24(16 \%)$ \\
\hline
\end{tabular}




\subsubsection{Analysis of immunocompetent cell populations in patients with GIC dependently on lymphocytes' count}

It was possible to divide patients with GIC into two groups according to the lymphocytes count: group I - patients without lymphopenia (lymphocytes $>1400$ cells in $1 \mathrm{~mm}^{3}$ of peripheral blood) and group II with lymphopenia (lymphocytes < 1400 cells in $1 \mathrm{~mm}^{3}$ of peripheral blood). Comparative analysis of immunocompetent cells' populations in both GIC patients groups showed significant differences in almost all rate. The mean number of leukocytes in the group I $\left(7910 \pm 1960 \times 10^{6} / \mathrm{L}\right)$ was significantly $\quad(\mathrm{p}=0.002)$ higher $(27 \%)$ than in the group II $\left(5830 \pm 2210 \times 10^{6} / \mathrm{L}\right)$. The mean absolute number of lymphocytes in the group I was two times (50\%) higher than in the group II $\left(2270 \pm 700 \times 10^{6} / \mathrm{L} ; 1140 \pm 210 \times 10^{6} / \mathrm{L}\right.$, respectively; $\left.\mathrm{p}=0.0001\right)$. Comparative analyses of lymphocytes' subsets between the group I and II $\left(\mathrm{CD}^{+}, \mathrm{CD}^{+}, \mathrm{CD} 8^{+}, \mathrm{CD} 38^{+}, \mathrm{CD} 16^{+}, \mathrm{CD} 19^{+}, \mathrm{CD} 25^{+}\right.$and $\left.\mathrm{CD} 95^{+}\right)$showed significant decrease of immunological parameters in the group II approximately in two times in comparison with the group I (Table 2.5). 
Absolute counts of immunocompetent cell populations in the I and II GIC patients' groups

\begin{tabular}{|c|c|c|c|c|c|}
\hline \multirow[t]{2}{*}{ Parameters } & \multicolumn{2}{|c|}{ Group I Ly > $1400(n=35)$} & \multicolumn{2}{|c|}{ Group II Ly < $1400(\mathrm{n}=30)$} & \multirow{2}{*}{$\begin{array}{l}\mathrm{p} \leq \\
0.05\end{array}$} \\
\hline & $\begin{array}{c}\text { Absolute count } \\
\pm \mathrm{SD}\end{array}$ & $\begin{array}{c}\text { Count } \\
\%\end{array}$ & $\begin{array}{c}\text { Absolute count } \\
\pm \mathrm{SD}\end{array}$ & Count \% & \\
\hline Leu & $7910 \pm 1960$ & & $5830 \pm 2210$ & & 0.002 \\
\hline Ly & $2270 \pm 700$ & 28.83 & $1140 \pm 210$ & 19.88 & 0.0001 \\
\hline $\mathrm{CD}^{+}$ & $1600 \pm 580$ & 70.77 & $780 \pm 180$ & 70.77 & 0.0001 \\
\hline $\mathrm{CD}^{+}{ }^{+}$ & $880 \pm 330$ & 39.29 & $450 \pm 130$ & 39.00 & 0.0001 \\
\hline $\mathrm{CD}^{+}$ & $680 \pm 370$ & 29.11 & $330 \pm 120$ & 31.08 & 0.0001 \\
\hline $\mathrm{CD}^{2} 8^{+}$ & $660 \pm 300$ & 29.03 & $320 \pm 90$ & 28.40 & 0.0001 \\
\hline $\mathrm{CD}^{2} 6^{+}$ & $460 \pm 310$ & 19.69 & $220 \pm 130$ & 19.4 & 0.0015 \\
\hline $\mathrm{CD} 19^{+}$ & $190 \pm 110$ & 8.03 & $110 \pm 60$ & 7.00 & 0.0018 \\
\hline $\mathrm{CD}^{2} 5^{+}$ & $1130 \pm 370$ & 50.89 & $520 \pm 130$ & 48.8 & 0.0001 \\
\hline $\mathrm{CD}^{2} 5^{+}$ & $180 \pm 150$ & 8.63 & $80 \pm 50$ & 7.50 & 0.047 \\
\hline $\mathrm{CD}^{+} / \mathrm{CD}^{+}$ & $1.58 \pm 0.85$ & & $1.18 \pm 0.57$ & & \\
\hline
\end{tabular}

\subsubsection{Presence of HHV-6 and HHV-7 infection in GIC patients with and without lymphopenia}

Frequency of single HHV-6 persistent infection was significantly $(\mathrm{p}<0.05)$ higher in patients with lymphopenia $(2 / 35 ; 6.6 \%)$ than in patients without it $(1 / 30 ; 2.6 \%)$, however, presence of single HHV-7 persistent infection was higher in patients from the group I $(20 / 35 ; 57 \%)$ than from the group II $(8 / 30 ; 27 \%)$. Double persistent infection was more frequently detected in patients with $(9 / 30 ; 30 \%)$ than in patients without $(4 / 35 ; 11 \%)$ lymphopenia.

There was significant difference in the presence of single HHV-6 latent infection between two analysed groups, however, higher rate of single HHV-7 
latent infection was found in the group I patients (17/20; 85\%) comparing with the group II patients $(4 / 8 ; 50 \%)$. Frequency of double latent infection was found more frequent in patients without lymphopenia $(4 / 4 ; 100 \%)$ than in patients with lymphopenia $(3 / 9 ; 33 \%)$.

In the group of patients without lymphopenia significantly $(\mathrm{p}=0.002)$ lower incidence of active beta-herpesviruses infection was detected $(3 / 25,12 \%)$ than in patients with lymphopenia $(11 / 19,58 \%)$. Active single HHV-6 infection was detected only in one out of two patients with GIC from the group II. Presence of single HHV-7 active infection was higher in $(4 / 8 ; 50 \%)$ patients from the group II comparing with patients from the group I $(3 / 20 ; 15 \%)$. Double HHV-6 + HHV-7 active infection was found only in patients with lymphopenia $(6 / 9 ; 64 \%)$ (Table 2.6).

Table 2.6.

\section{Presence of latent and active beta-herpesviruses HHV-6 and HHV-7 infection in GIC patients group I and II}

\begin{tabular}{|l|l|l|l|c|}
\hline Patients & $\begin{array}{l}\text { HHV-6 } \\
\text { persistent } \\
\text { (latent/active) } \\
\text { infection }\end{array}$ & $\begin{array}{l}\text { HHV-7 } \\
\text { persistent } \\
\text { (latent/active) } \\
\text { infection }\end{array}$ & $\begin{array}{l}\text { HHV-6 + HHV-7 } \\
\text { persistent } \\
\text { (latent/active) } \\
\text { infection }\end{array}$ & $\begin{array}{l}\text { Without HHV- } \\
6 \text { or HHV-7 } \\
\text { infection }\end{array}$ \\
\hline $\begin{array}{l}\text { Group I } \\
(\mathrm{n}=35)\end{array}$ & $1(2.8 \%)$ & $20(57 \%)$ & $4(11 \%)$ & $10(29 \%)$ \\
$(1 / 0)$ & $(17 / 3)$ & $8(27 \%)$ & $9(30 \%)$ & $11(37 \%)$ \\
\hline $\begin{array}{l}\text { Group II } \\
(\mathrm{n}=30)\end{array}$ & $2(6.6 \%)$ & $(4 / 4)$ & $(3 / 6)$ & \\
\hline
\end{tabular}




\subsubsection{Comparative analysis of immunocompetent cell populations in GIC patients without and with lymphopenia dependently on beta-herpesviruses infection}

Comparative analysis of immunocompetent cell populations in the group I and II was performed dependently on beta-herpeviruses infection. Each group was subdivided into three subgroups: GIC patients without, with latent and with active HHV-6 and/or HHV-7 infection.

The group I patients with active viral infection had tendency to increase all cellular immunological parameters (leukocytes, monocytes, lymphocytes and $\mathrm{CD}^{+}, \mathrm{CD}^{+}, \mathrm{CD} 8^{+}, \mathrm{CD} 38^{+}, \mathrm{CD} 16^{+}, \mathrm{CD} 19^{+}, \mathrm{CD} 25^{+}, \mathrm{CD} 95^{+}$) comparing with subgroups with and without latent HHV-6 and HHV-7 infection. The most dramatic decrease was found in $\mathrm{CD}^{+}$and $\mathrm{CD}^{+}$subpopulations (to $16 \%$ and to $21 \%$, respectively) in the group II patients with active beta-herpesviruses infection. Tendency to increase was detected in both patient groups' B lymphocytes $\left(\mathrm{CD} 19^{+}\right)$during active viral infection. However, patients without lymphopenia had increase to $105 \%$ of $\mathrm{CD} 19^{+}$subpopulation, but in patients with lymphopenia only to $18 \%$. The logistic regression analysis showed that patients with active viral infection have higher risk of lymphopenia (OR 3.33; 95\% CI $0.72-15.51 ; \mathrm{p}=0.0035)$ than patients with latent viral infection (OR $0.33 ; 95 \%$ CI $0.10-1.07 ; \mathrm{p}=0.0035)$.

\subsubsection{Pro-inflammatory cytokines levels in GIC patients with and without lymphopenia}

There were no significant changes in the plasma levels of IL-6, IL-1 $\beta$, sIL-2R and TNF-alpha between GIC patients of the group I and II. However, in 
the group I and II of patients with active viral infection the levels of IL-6 and sIL-2R had tendency to increase, nonetheless, level of TNF-alpha in the group II patients with active viral infection was lower than in patients with latent and without viral infection, and also lower in comparison with the group I patients with active viral infection (Table 2.7).

Table 2.7.

\section{Levels of IL-1beta, IL-6, sIL2R and TNF-alpha in the patients with GIC group I and II}

\begin{tabular}{|c|c|c|c|c|}
\hline Patients groups & 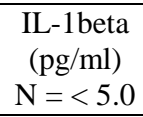 & $\begin{array}{c}\text { IL-6 (U/ml) } \\
\mathrm{N}=3.4\end{array}$ & $\begin{array}{l}\text { sIL2R }(\mathrm{U} / \mathrm{ml}) \\
\mathrm{N}=223-710\end{array}$ & $\begin{array}{c}\text { TNF-alpha } \\
\text { (pg/ml) } \\
\mathrm{N}=8.1\end{array}$ \\
\hline $\begin{array}{l}\text { Group I }(\mathrm{n}=10) \\
\text { Without HHV-6 } \\
\text { and/or HHV-7 }\end{array}$ & $<5.0$ & $4.08 \pm 1.23$ & $527 \pm 159.58$ & $15.13 \pm 5.15$ \\
\hline $\begin{array}{l}\text { Group II }(\mathrm{n}=11) \\
\text { Without HHV-6 } \\
\text { and/or HHV-7 }\end{array}$ & $<5.0$ & $5.15 \pm 2.76$ & $559.80 \pm 379.10$ & $15.58 \pm 5.66$ \\
\hline $\begin{array}{l}\text { Group I }(\mathrm{n}=22) \\
\text { HHV-6 and/or } \\
\text { HHV-7 latent } \\
\text { ifection }\end{array}$ & $<5.0$ & $5.44 \pm 2.99$ & $604.78 \pm 242.33$ & $11.62 \pm 1.08$ \\
\hline $\begin{array}{l}\text { Group II }(\mathrm{n}=8) \\
\text { HHV-6 and/or } \\
\text { HHV-7 latent } \\
\text { infection }\end{array}$ & $<5.0$ & $5.55 \pm 1.91$ & $617.00 \pm 173.20$ & $13.83 \pm 3.06$ \\
\hline $\begin{array}{l}\text { Group I }(\mathrm{n}=3) \\
\text { HHV-6 and/or } \\
\text { HHV-7 active } \\
\text { infection }\end{array}$ & $<5.0$ & $7.20 \pm 11.88$ & $851 \pm 528.55$ & $14.40 \pm 5.31$ \\
\hline $\begin{array}{l}\text { Group II }(\mathrm{n}=11) \\
\text { HHV-6 and/or } \\
\text { HHV-7 active } \\
\text { infection }\end{array}$ & $<5.0$ & $6.18 \pm 2.91$ & $733.67 \pm 388.76$ & $9.78 \pm 4.23$ \\
\hline
\end{tabular}




\subsubsection{Gastrointestinal cancer clinical outcomes dependently on beta-herpesviruses infection}

Stages of gastrointestinal cancer were defined in accordance to TNM evaluation (evaluation of the (primary) tumor ' $\mathrm{T}$ '; evaluation of the regional lymph nodes 'N'; evaluation of distant metastasis 'M'). First stage was defined only in $9 \%$ of patients. The majority of patients (43\%) were with second stage of cancer. Third stage was defined in $30 \%$ patient and the most severe - fourth stage was defined in $18 \%$ patients with GIC. There was no association between beta-herpesviruses infection and stages of cancer; however, fourth stage of cancer was more prevalent in patients with HHV-6 and/or HHV-7 persistent infection (23\%) than in patients without it $(6 \%)$ (Table 2.8). Also, no association between lymphopenia and stages of cancer was found. However, death rate was higher in patients with lymphopenia (53\%) than in patients without it (34\%), but there was no statistical significance.

Table 2.8.

Stages of GIC frequency dependently on beta-herpesviruses infection

\begin{tabular}{|c|c|c|c|c|c|}
\hline $\begin{array}{l}\text { Stage of } \\
\text { cancer }\end{array}$ & $\begin{array}{l}\text { Without HHV- } \\
6 \text { and/or HHV- } \\
7(n=21)\end{array}$ & $\begin{array}{l}\text { Persistent } \\
\text { HHV-6 and/or } \\
\text { HHV-7 } \\
\text { infection } \\
(\mathrm{n}=44)\end{array}$ & $\begin{array}{l}\text { Stage of } \\
\text { cancer }\end{array}$ & $\begin{array}{l}\text { Latent HHV- } \\
6 \text { and/or } \\
\text { HHV-7 } \\
\text { infection } \\
(n=30) \\
\end{array}$ & $\begin{array}{l}\text { Active HHV-6 } \\
\text { and/or HHV-7 } \\
\text { infection } \\
(n=14)\end{array}$ \\
\hline I stage & $4(19 \%)$ & $3(7 \%)$ & I stage & $1(4 \%)$ & $2(15 \%)$ \\
\hline II stage & $9(44 \%)$ & $19(43 \%)$ & II stage & $13(44 \%)$ & $6(39 \%)$ \\
\hline III stage & $7(31 \%)$ & $12(27 \%)$ & III stage & $8(26 \%)$ & $4(31 \%)$ \\
\hline IV stage & $1(6 \%)$ & $10(23 \%)$ & IV stage & $8(26 \%)$ & $2(15 \%)$ \\
\hline
\end{tabular}




\subsection{Involvement of HHV-6 and HHV-7 infection in the development of autoimmune thyroid diseases (AIT)}

\subsubsection{Presence of HHV-6 and HHV-7 infection in patients with AIT}

Presence of beta-herpesviruses infection markers in blood samples were found more frequently in patients with AIT than in healthy blood donors (93\% and $84 \%$, respectively). HHV-6 persistent infection was detected in 12 out of $44(27 \%)$ patients with AIT. The same infection frequency was detected in healthy blood donors $(43 / 150,29 \%)$. HHV-7 persistent infection was revealed in 40 out of $44(91 \%)$ patients with AIT. Presence of HHV-7 was found to be significantly lower $(\mathrm{p}=0.03)$ in healthy individuals (only $75 \%)$.

Single HHV-6 and HHV-7 persistent infection was more frequently observed in blood donors ( $8.6 \%$ and $55 \%$, respectively) comparing to AIT patients (2.3\% and 36\%, respectively). Frequency of double HHV-6+HHV-7 persistent infection was much higher in patients with AIT than in blood donors (55\% against $20 \%$, respectively) (Table 2.9 ).

Single HHV-6 active infection was not found neither in patients with AIT and in healthy blood donors. Activation rate of single HHV-7 infection was significantly higher $(\mathrm{p}<0.0001)$ in patients with AIT comparing with blood donors (38\% and 15\%, respectively). Double HHV-6 + HHV-7 active infection was found only in patients with AIT (13/44, 30\%). 
Table 2.9.

Presence of HHV-6 and HHV-7 infection in patients with AIT

\begin{tabular}{|l|c|c|c|c|}
\hline & $\begin{array}{c}\text { HHV-6 } \\
\text { persistent } \\
\text { (latent/active) } \\
\text { infection }\end{array}$ & $\begin{array}{c}\text { HHV-7 } \\
\text { persistent } \\
\text { (latent/active) } \\
\text { infection }\end{array}$ & $\begin{array}{c}\text { HHV-6 + HHV-7 } \\
\text { persistent } \\
\text { (latent/active) } \\
\text { infection }\end{array}$ & $\begin{array}{c}\text { Without } \\
\text { HHV-6 or } \\
\text { HHV-7 } \\
\text { infection }\end{array}$ \\
\hline $\begin{array}{l}\text { Patients } \\
\text { with AIT } \\
\text { n=44) }\end{array}$ & $1(2.3 \%)$ & $16(36 \%)$ & $24(55 \%)$ & 3 \\
\hline $\begin{array}{l}\text { Blood } \\
\text { donors } \\
(n=150)\end{array}$ & $(1 / 0)$ & $(10 / 6)$ & $(11 / 13)$ & $(7 \%)$ \\
\hline
\end{tabular}

\subsubsection{Analysis of immunocompetent cell populations in patients with AIT dependently on viral infection}

Comparative analysis of immunocompetent cell populations in the patients with AIT was performed dependently on beta-herpesviruses infection. Patients were subdivided into three subgroups: AIT patients without, with latent and with active HHV-6 and/or HHV-7 infection. As in previous groups, patients with latent HHV-6 and/or HHV-7 infection had increase almost in all immunological parameters (Ly, $\mathrm{CD}^{+}, \mathrm{CD}^{+}, \mathrm{CD}^{+}, \mathrm{CD} 16^{+}, \mathrm{CD} 19^{+}$and $\mathrm{CD}^{+}$) comparing to patients without viral infection and patients with active viral infection. In patients with active HHV-6 and/or HHV-7 infection decrease in all immunocompetent cell populations was observed in comparison with the patients with latent infection however statistical analysis showed no significance (Table 2.10). 
Table 2.10.

Analysis of cellular immune parameters in AIT patients dependently on beta-herpesvirus infection

\begin{tabular}{|l|l|l|l|}
\hline Parameters & $\begin{array}{l}\text { Without HHV-6 and/or } \\
\text { HHV-7 }(\mathrm{n}=3)\end{array}$ & $\begin{array}{c}\text { Latent HHV-6 and/or } \\
\text { HHV-7 }(\mathrm{n}=21)\end{array}$ & $\begin{array}{c}\text { Active HHV-6 and/or } \\
\text { HHV-7 }(\mathrm{n}=20)\end{array}$ \\
\hline Leu & $5833 \pm 1401$ & $6073 \pm 1297$ & $6252 \pm 1597$ \\
\hline Ly & $1883 \pm 188$ & $2087 \pm 732$ & $1994 \pm 427$ \\
\hline $\mathrm{CD}^{+}$ & $1312 \pm 131$ & $1454 \pm 510$ & $1390 \pm 297$ \\
\hline $\mathrm{CD}^{+}$ & $497 \pm 49$ & $551 \pm 193$ & $527 \pm 112$ \\
\hline $\mathrm{CD}^{+}$ & $283 \pm 28$ & $314 \pm 110$ & $300 \pm 64$ \\
\hline $\mathrm{CD} 16^{+}$ & $376 \pm 37$ & $417 \pm 146$ & $399 \pm 86$ \\
\hline $\mathrm{CD} 19^{+}$ & $163 \pm 16$ & $181 \pm 63$ & $173 \pm 37$ \\
\hline $\mathrm{CD} 95^{+}$ & $1160 \pm 115$ & $1285 \pm 450$ & $1228 \pm 263$ \\
\hline $\mathrm{CD}^{+} / \mathrm{CD}^{+}$ & $0.9 \pm 0.3$ & $1.33 \pm 0.85$ & $1.14 \pm 0.56$ \\
\hline
\end{tabular}

\subsubsection{Presence of HHV-6 and HHV-7 infection in thyroid gland tissue}

Beta-herpesviruses HHV-6 and HHV-7 persistent infection was detected in 43 out of $44(98 \%)$ of AIT patients' thyroid tissue DNA samples and in 31 out of $41(76 \%)$ control group autopsies' DNA samples ( $p=0.003)$. In 42 (95\%) of the 44 patients with AIT in tissue DNA samples HHV-6 genomic sequence was found, whereas in the control group HHV-6 genome sequence was found in 25 out of $41(61 \%)$ autopsy tissue DNA samples ( $<<0.0001)$.

HHV-7-specific genomic sequence was presented in 33 (75\%) out of 44 patients with AIT and in 16 (39\%) out of 41 thyroid tissue DNA samples extracted from control group autopsies $(\mathrm{p}=0.001)$. There was no significant difference in the presence of single HHV-6 and HHV-7 genomic sequences in patients' and control group thyroid tissue DNA, however, simultaneous 
presence of HHV-6 and HHV-7 genomic sequences in tissue DNA samples was significantly higher $(\mathrm{p}<0.0001)$ in patients with AIT (Table 11).

Presence of HHV-6 genomic sequence in thyroid tissue DNA samples was significantly more prevalent $(\mathrm{p}=0.01)$ than the presence of HHV-7 genomic sequence (95\% and $75 \%$, respectively).

Table 2.11.

\section{Presence of beta-herpesviruses (HHV-6 and HHV-7) infection in AIT patients' thyroid tissue DNA samples and autopsy materials}

\begin{tabular}{|l|c|c|c|c|}
\hline & HHV6 & HHV-7 & HHV-6 + HHV-7 & Without \\
\hline AIT $(\mathrm{n}=44)$ & $10(23 \%)$ & $1(2.3 \%)$ & $32(73 \%)$ & $1(2.3 \%)$ \\
\hline Control group $(\mathrm{n}=41)$ & $15(36 \%)$ & $6(15 \%)$ & $10(24 \%)$ & $10(24 \%)$ \\
\hline
\end{tabular}

\subsubsection{Comparison of HHV-6 infection presence in thyroid gland tissue and blood samples}

In $43(98 \%)$ of the 44 patients with AIT HHV-6 genomic sequence in blood and/or thyroid tissue DNA samples was found: in 17 (39\%) patients, HHV-6 genomic sequence was detected in both tissue and blood DNA samples, while in $25(58 \%)$ patients viral genomic sequence was detected only in tissue DNA samples. In contrast, HHV-6 genome sequence was found in $25(61 \%)$ DNA samples isolated from control groups' autopsy materials: in 14 (34\%) cases in both blood and tissue DNA samples, and in 11 (27\%) cases only in tissue DNA samples. Presence of HHV-6 genomic sequence in thyroid gland 
tissue only was significantly higher in patients with AIT comparing to the control group $(\mathrm{p}=0.008)$.

Table 2.12.

Presence of HHV-6 sequence in peripheral blood and thyroid tissue DNA of patients with AIT and control group autopsy material

\begin{tabular}{|l|c|c|}
\hline $\begin{array}{c}\text { Distribution of HHV-6 genomic } \\
\text { sequence }\end{array}$ & $\begin{array}{c}\text { Number of patients } \\
\text { with AIT }(\mathrm{n}=44)\end{array}$ & $\begin{array}{c}\text { Number of control } \\
\text { group samples }(\mathrm{n}=41)\end{array}$ \\
\hline Only blood DNA & 1 & 0 \\
\hline Blood DNA + tissue DNA & 17 & 14 \\
\hline Only tissue DNA & 25 & 11 \\
\hline Blood DNA+plasma DNA & 0 & 0 \\
\hline $\begin{array}{l}\text { Tissue DNA+blood } \\
\text { DNA+plasma DNA }\end{array}$ & 0 & 0 \\
\hline Without & 1 & 16 \\
\hline
\end{tabular}

\subsubsection{HHV-6 load in blood and tissue DNA}

Using real-time polymerase chain reaction HHV-6 load was determined in DNA samples from patients' whole blood, tissue and main lymphocyte subpopulations $\left(\mathrm{CD}^{+}, \mathrm{CD} 8^{+}, \mathrm{CD} 16^{+}, \mathrm{CD} 19^{+}\right.$and $\left.\mathrm{CD}^{+} 5^{+}\right)$DNA samples. In patients' blood DNA samples the average viral load was $98 \pm 44$ copies $/ 1 \times 10^{6}$ cells while in the tissue DNA samples viral load in average was $2552 \pm 2015$ copies $/ 1 \times 10^{6}$ cells.

To ensure that detected HHV-6 sequence in DNA samples is due to the involvement of thyroid gland tissue but not due to lymphocyte infiltration, the main lymphocyte subpopulations DNA was also examined by real-time polymerase chain reaction. Substantial HHV-6 viral load in lymphocyte 
subpopulation was detected in two out of seven patients. In first patient, who was positive for the presence of HHV-6 genomic sequence by nPCR in whole blood and tissue DNA, HHV-6 load was detected in NK and CD95 ${ }^{+}$cells (24 and 100 copies $/ 1 \times 10^{6}$ cells, respectively). In this patient also lower HHV-6 load was detected in whole blood DNA ( 27 copies $/ 1 \times 10^{6}$ cells) comparing to tissue DNA, where HHV-6 load was 355 copies $/ 1 \times 10^{6}$ cells (Figure 2.1 ). In second patient, who was positive for the presence of HHV-6 genomic sequence by nPCR only in tissue DNA, HHV-6 load was detected only in $\mathrm{CD} 95^{+}$cells. HHV-6 load in $\mathrm{CD} 95^{+}$cells was 11 copies $/ 1 \times 10^{6}$ cells (Figure 2.2 ). In other five patients' lymphocyte subpopulations $\left(\mathrm{CD}^{+}, \mathrm{CD}^{+} 6^{+}\right.$and $\left.\mathrm{CD}^{+} 5^{+}\right) \mathrm{DNA}$ insignificant (according to the manufacturer's protocol) HHV-6 load was detected (range $14-20$ copies $/ 1 \times 10^{6}$ cells).

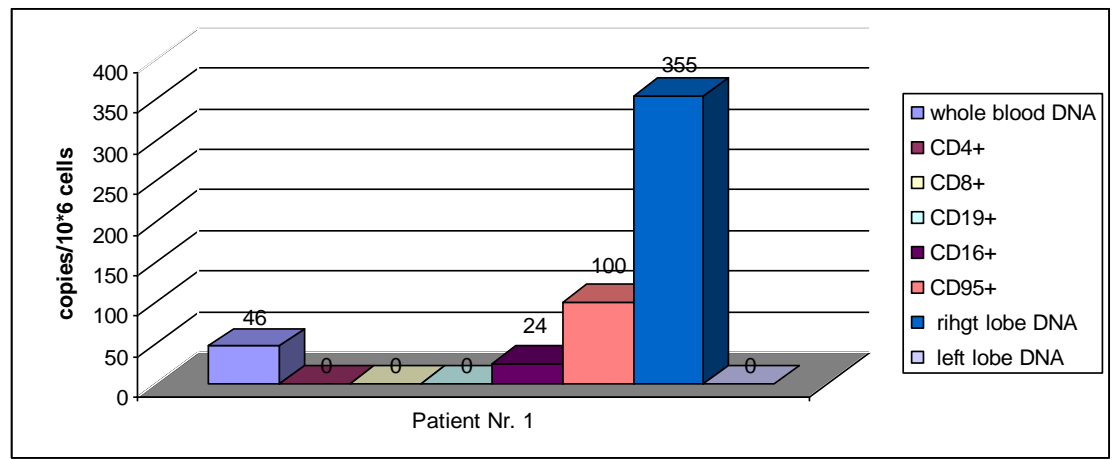

\begin{tabular}{|l|c|c|c|c|}
\hline & $\begin{array}{c}\text { Whole } \\
\text { blood DNA }\end{array}$ & Plasma & $\begin{array}{c}\text { Thyroid } \\
\text { gland right } \\
\text { lobe }\end{array}$ & $\begin{array}{c}\text { Thyroid } \\
\text { gland left } \\
\text { lobe }\end{array}$ \\
\hline $\begin{array}{l}\text { HHV-6 viral } \\
\text { sequence by nested } \\
\text { PCR }\end{array}$ & + & - & + & - \\
\hline
\end{tabular}

Figure 2.1. HHV-6 load in DNA samples of whole blood, tissue and main lymphocyte subpopulations in Patient Nr.1; nested PCR results 


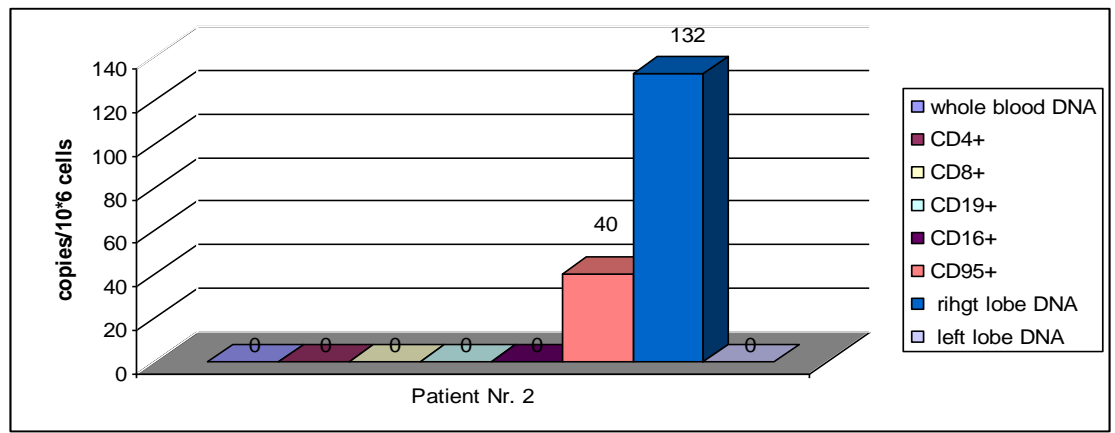

\begin{tabular}{|l|c|c|c|c|}
\hline & $\begin{array}{c}\text { Whole blood } \\
\text { DNA }\end{array}$ & Plasma & $\begin{array}{c}\text { Thyroid gland } \\
\text { right lobe }\end{array}$ & $\begin{array}{c}\text { Thyroid gland } \\
\text { left lobe }\end{array}$ \\
\hline $\begin{array}{c}\text { HHV-6 viral } \\
\text { sequence by } \\
\text { nested PCR }\end{array}$ & - & - & + & - \\
\hline
\end{tabular}

Figure 2.2. HHV-6 load in DNA samples of whole blood, tissue and main lymphocyte subpopulations in Patient Nr.2; nested PCR results

\subsection{Comparative analysis between patients with different immune system dysfunctions}

\subsubsection{Comparison of beta-herpesviruses infection frequency}

The highest frequency of HHV-6 and HHV-7 persistent infection was detected in patients with AIT (93\%) in comparison with other two groups. The significantly lowest rate of beta-herpesviruses presence (68\%) was detected in patients with GIC $(\mathrm{p}<0.05)$ comparing to the renal transplant recipients and patients with AIT (Figure 2.3). 


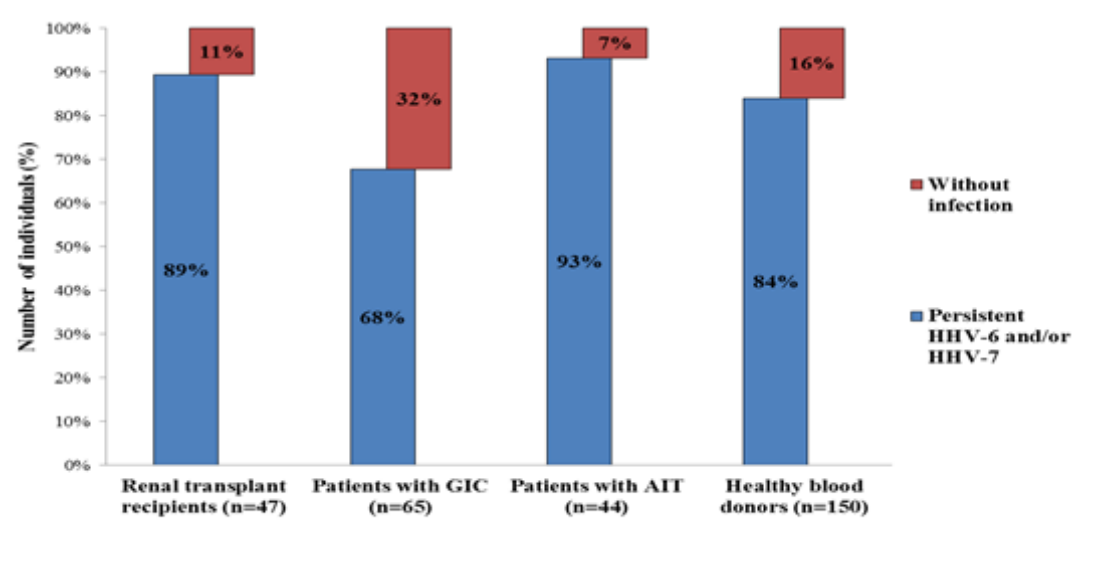

Figure 2.3. Presence of beta-herpesviruses persistent infection in three groups of patients

There was no significant difference in frequency of single HHV-6 latent infection between the groups, however, in patients with GIC higher frequency of single HHV-7 latent infection was detected in comparison with AIT patients ( $p=0.04)$ and with renal transplant recipients (without statistical significance). Double (HHV-6 + HHV-7) latent infection was found higher in patients with AIT (27\%) than in renal transplant recipients (12\%) and in patients with GIC (16\%), however, statistical analysis showed no significance.

Single HHV6 active infection was found only in renal transplant recipients and in patients with GIC without significant difference in frequency. Higher frequency of single HHV-7 active infection was found in renal transplant recipients $(26 \%)$ than in patients with GIC (16\%) and patients with AIT (15\%). Presence of double HHV-6 + HHV-7 active infection was more 
frequently detected in patients with AIT (32\%) comparing to renal transplant recipients (19\%) and patients with GIC (14\%) (Figure 2.4).

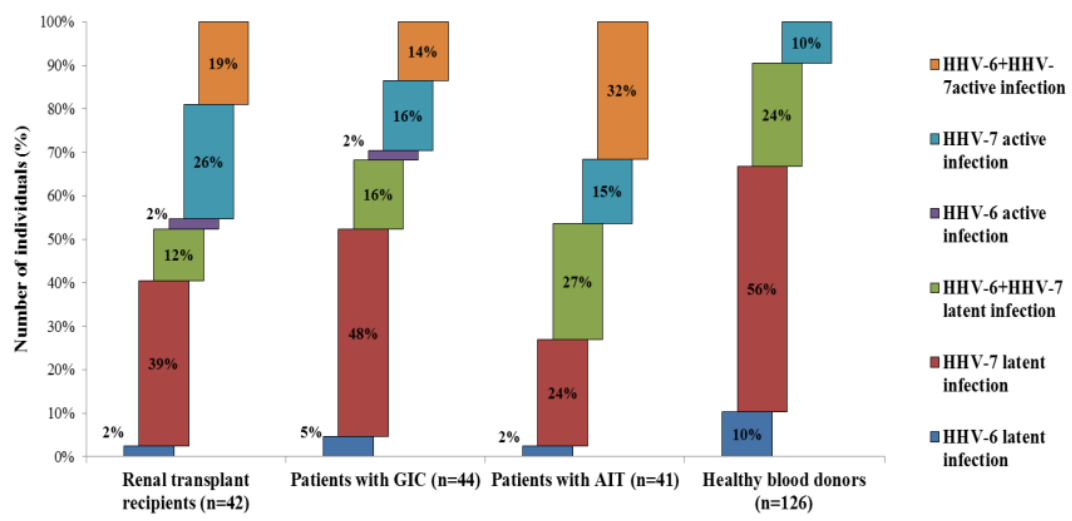

Figure 2.4. Presence of latent and active beta-herpesviruses infection in three groups of patients

\subsubsection{Comparison of immunocompetent cell populations dependently on beta-herpesviruses infection}

Despite of more severe immunosuppression in renal transplant recipients, in this group of patients' level of leukocytes (Leu) was the highest between all patients group. If in renal transplant recipients and patients with GIC mean absolute count of Leu had increased during beta-herpesviruses latent infection and had decreased during active infection, in patients with AIT increase of Leu absolute count was observed during latent as well as active infection. 
Comparative analysis of immunocompetent cell populations dependently on beta-herpesviruses infection in patients with AIT and two other groups of patients with immunosuppression of different origin showed remarkable differences in immunological parameter changes. During HHV-6 and/or HHV-7 latent infection in patients with AIT constant increase (to 11\%) in all immunocompetent cell populations $\left(\mathrm{Ly}, \mathrm{CD}^{+}, \mathrm{CD}^{+}, \mathrm{CD} 8^{+}, \mathrm{CD} 16^{+}\right.$, $\mathrm{CD} 19^{+}$and $\mathrm{CD}^{+} 5^{+}$) was observed and constant decrease (to $4 \%$ ) during active infection.

Increase of Ly count was detected in renal transplant recipients (to 13\%) and in patients with GIC (to 14\%) in case of beta-herpesviruses latent infection. However, during HHV-6 and/or HHV-7 active infection decrease in Ly number was found in both groups (to $19 \%$ in renal transplant recipients and to $12 \%$ in patients with GIC). Almost the same tendency was observed in level of $\mathrm{CD}^{+}$ subpopulation (increase during latent infection to $18 \%$ in transplant recipients and to $15 \%$ in patients with GIC, decrease during active infection - to $18 \%$ in renal transplant recipients and to $12 \%$ in patients with GIC). Remarkable increase of $\mathrm{CD}^{+}$number was detected in renal transplant recipients (to $41 \%$ ) during beta-herpesviruses latent infection comparing to GIC patients (to 19\%) and patients with AIT (to 11\%). In all three groups of patients also increase in $\mathrm{CD}^{+}$subpopulation (to $11 \%$ in all groups) was observed. However, increase in $\mathrm{CD} 16^{+}$subpopulation was observed during latent infection only in patients with AIT (to $11 \%$ ).

Number of leukocytes and levels of another immunocompetent cell subpopulations $\left(\mathrm{CD}^{+}, \mathrm{CD} 4^{+}, \mathrm{CD} 8^{+}, \mathrm{CD} 38^{+}, \mathrm{CD} 19^{+}, \mathrm{CD} 25^{+}\right.$and $\left.\mathrm{CD} 95^{+}\right)$were increased in renal transplant recipients and patients with GIC during latent betaherpesvirus infection comparing to the subgroups without viral infection. Comparison of both groups showed significant differences in numbers of $\mathrm{CD} 4^{+}$, 
$\mathrm{CD} 16^{+}, \mathrm{CD} 19^{+}$and $\mathrm{CD} 25^{+}$subpopulations $(\mathrm{p}<0.05)$ between patients with latent and active beta-herpesvirus infection. In renal transplant recipients with active viral infection mean absolute number of $\mathrm{CD}^{+}$lymphocytes was decreased to $14 \%$ and in GIC patients to $19 \%$ in comparison with patients with latent infection. The most dramatic decrease was detected in number of CD16 ${ }^{+}$, where in renal transplant recipients with active viral infection this subpopulation was decreased to $24 \%$ and in the patients with GIC only to $11 \%$ comparing both patients groups with latent viral infection. Another interesting finding was revealed in patients' groups with active beta-herpesvirus infection. Number of B lymphocytes $\left(\mathrm{CD} 19^{+}\right)$had tendency to decrease in renal transplant recipients (to 10\%) and in patients with AITD (to 4\%), however in GIC patients it had tendency to increase (to $26 \%$ ).

By comparative analysis of immunocompetent cell subpopulations in all three patients groups greater differences in cell counts were detected between renal transplant recipients and patients with AIT. Mean absolute count of Ly was significantly higher $(\mathrm{p}<0.0001)$ in patients with AIT during latent $(2087 \pm$ 732) and active (1994 \pm 427) HHV-6/7 infection comparing with transplant recipients (1350 \pm 700 and $1100 \pm 630$, respectively).

However, no significance was detected between patients with AIT and patients with GIC. Also, in patients with AIT significantly higher $(\mathrm{p}<0.0001)$ mean absolute count of $\mathrm{CD} 16^{+}$and $\mathrm{CD} 19^{+}$was found in comparison with renal transplant recipients. Significantly $(\mathrm{p}<0.005)$ higher amount of $\mathrm{CD}^{+} 5^{+}$was detected in AIT patients comparing to renal transplant recipients and patients with GIC. In its turn mean absolute number of $\mathrm{CD}^{+}$was significantly ( $\mathrm{p}<0.0001)$ higher in GIC patients with latent and active beta-herpesviruses infection comparing to patients with AIT (Figure 2.5). 


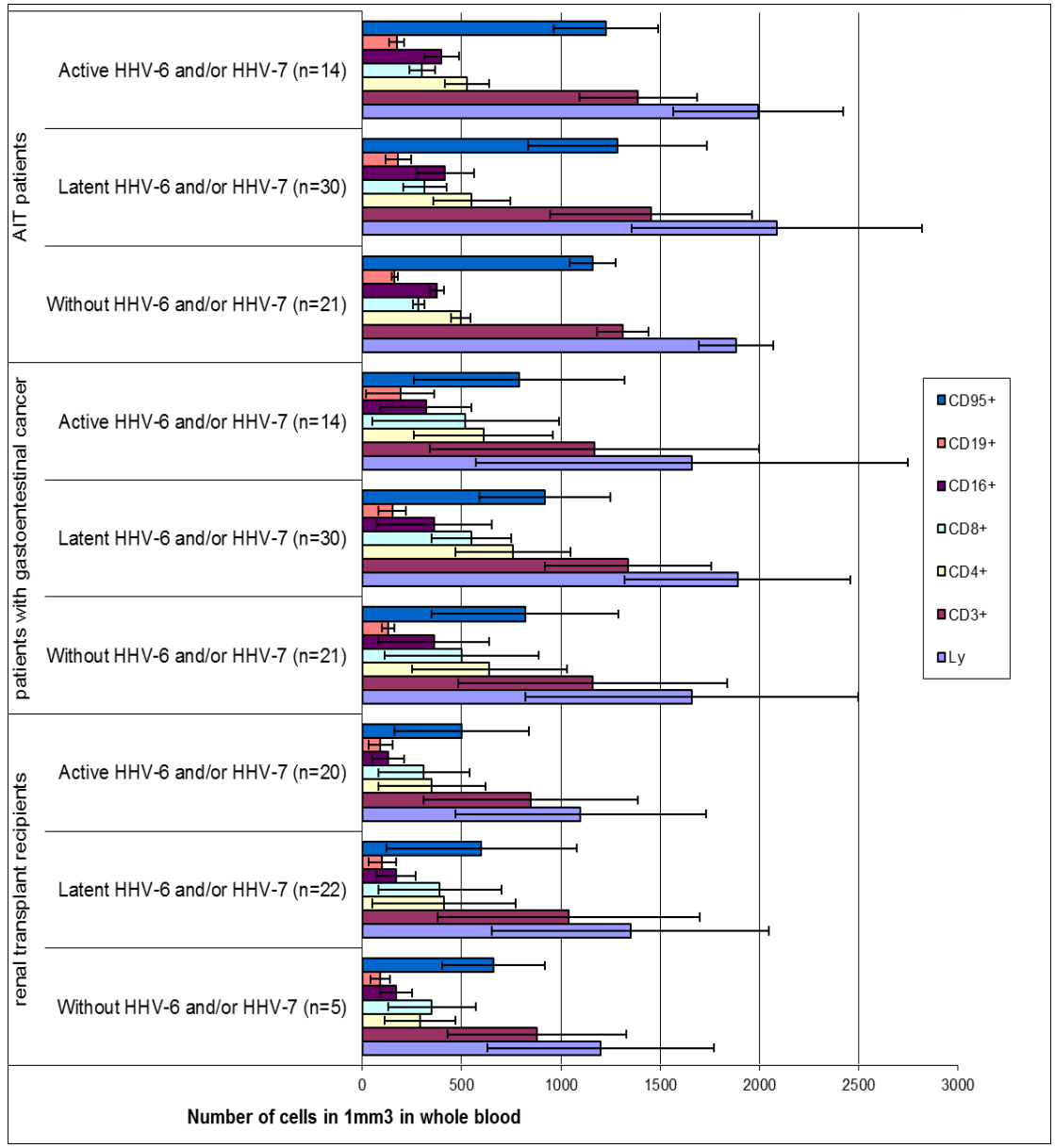

Figure 2.5. Comparison of immunocompetent cell populations dependently on beta-herpeviruses infection in three different patients groups 


\section{DISCUSSION}

Today there are a lot of studies trying to find and evaluate a role of betaherpesviruses infection in etiopathogenesis of different kinds of chronic diseases, but the final answer to this question is still not found. It could be due their ubiquitous nature and different mechanisms of interference that these viruses are using. But one common feature can unite all viruses - it is disturbance in the immune system, especially immunosuppression, caused by different origin that is a base for beta-herpesviruses reactivation. Betaherpesviruses in the host can function both - directly and indirectly, that means the viruses infect cells involved in the cellular and humoral immune response formation, and at the same time these viruses alter cell surface receptor expression, as well as proinflammatory cytokine (IL-12, IL - $1 \beta$, IL-6, TNF- $\alpha$, IFN- $\gamma$ ) and chemokine expression levels, thereby contributing to a local inflammation.

This work shows results obtained by comparison of beta-herpesviruses infection and disease or complications development in three different groups of patients with different types of immune system dysfunctions. Renal transplant recipients have immunosuppression caused by medical treatment (immunosuppressants), GIC patients - immunosuppression caused by underlying disease and patients with autoimmune thyroid disease (AIT) - immunosuppression caused by immune system dysfunction.

Comparison of immunocompetent cell populations shows more severe immunosuppression in renal transplant recipients (almost two fold decrease in all parameters comparing with other two patient groups). This fact is crucial for the patients with beta-herpesviruses active infection because this group has showed more pronounced downfall of all Ly subsets than in other two groups 
of patients and reactivation of these viruses can cause more severe complications.

In this group also higher incidence of beta-herpesviruses infection comparing to GIC patients ( $89 \%$ versus $68 \%$ ) is found. Single HHV-7 active infection is more prevalent in renal transplant recipients $(26 \%)$ in comparison with patients with GIC (16\%) and patient with AIT (15\%), however without statistical significance. This finding indicates that HHV-7 important role in immunosuppression is worsening the clinical outcome in these patients.

Comparative analysis of cellular immune parameters dependently on beta-herpeviruses infection shows significantly lower level $(14 \%, \mathrm{p}<0.0001)$ of natural killer cells $\left(\mathrm{CD}^{+} 6^{+}\right)$in renal transplant recipients with active viral infection than in GIC patients (19.5\%) and patients with AIT (20\%). Decrease of $\mathrm{CD}^{+} 6^{+}$number in this group could be caused by immunosuppressive therapy and higher rate of $\mathrm{HHV}-7$ activation.

Development of complications is detected in $30 \%$ of recipients and significantly higher rate $(\mathrm{p}=0.048)$ is found in renal transplant recipients with active beta-herpesviruses infection $(10 / 20,50 \%)$ than in recipients with latent infection $(4 / 22,18 \%)$. Also, logistic regression analysis shows higher risk of complication development in patients with active viral infection than with latent infection (OR 4.5; 95\% CI 1.12-18.13; $\mathrm{p}=0.03$ and OR 0.22; 95\% CI $0.06-0.89 ; \mathrm{p}=0.03$, respectively). This is an evidence of the HHV-6 and HHV-7 implication in complications development.

Concerning the patients with GIC, at present there is too little information on the-influence of beta-herpesviruses infection on the clinical course of the disease. Gastrointestinal malignancies are associated with a compromised immune system and viruses, such as immunotropic and immunomodulating HHV-6 and HHV-7 may be able to utilize cellular mechanisms 
responsible for the immune response inhibition. Modulation of functional properties of host immune factors is an important mechanism of evading the immune response or creating an environment in which the virus can survive.

Analysis for immunocompetent cell populations shows that only $46 \%$ of patients have lymphopenia ( $\mathrm{Ly}<1400$ cells in $1 \mathrm{~mm}^{3}$ peripheral blood), so it is interesting to compare these patients with GIC patients without lymphopenia (Ly > 1400 cells in $1 \mathrm{~mm}^{3}$ peripheral blood).

These results show that in GIC patients group with lymphopenia the activation of HHV-6 and HHV-7 infection is significantly more frequent $(\mathrm{p}=0.003)$. Moreover, comparative analysis of immunocompetent cell subpopulations shows decrease of preferable beta-herpesviruses cell target populations (absolute count of lymphocytes and $\mathrm{CD} 3^{+}, \mathrm{CD} 4^{+}, \mathrm{CD} 8^{+}$and $\mathrm{CD} 38^{+}$ subpopulations). Such difference in cell populations could be another evidence of HHV-6 and HHV-7 involvement in this disease progression. It should be pointed out that only in GIC patients without lymphopenia during active betaherpesviruses infection increase in absolute count of lymphocytes (to 9\%), $\mathrm{CD}^{+}$(to $13 \%$ ), $\mathrm{CD}^{+}$(to $19 \%$ ) and $\mathrm{CD}^{+}$(to $9 \%$ ) subpopulations is identified; however in all patients with lymphopenia these populations are decreased. This fact can be explained by the effect of immunosuppression on more frequent beta-herpesviruses activation which in turn subsequently affects the count of immunocompetent cells (decreasing their count). In conformation of this statement logistic regression analysis was done and it shows that patients with active viral infection have higher risk of lymphopenia (OR 3.33; 95\% CI 0.72-15.51; $\mathrm{p}=0.0035)$ than patients with latent viral infection (OR 0.33; 95\% CI 0.10-1.07; $\mathrm{p}=0.0035)$.

Although, development of the most sever (fourth) stage of GIC is more prevalent in patients with persistent beta-herpesviruses infection (23\%) than 
without viral infection (6\%), there is no significant association between cancer stages development and beta-herpesviruses infection. However, higher death rate $(53 \%)$ is found between the patients with than without (34\%) lymphopenia. This fact indicates that lymphopenia is an important factor that impacts the course of the disease, in its turn strong association of lymphopenia development and active beta-herpesviruses infection is shown.

All these results show importance of HHV-6 and also HHV-7 involvement in immunosuppression in both mentioned patients groups, however additional investigations are required to make general conclusion.

Viral infections have been frequently cited as important environmental factors implicated in AIT, but no specific virus has yet been conclusively associated to the disease. In particular, herpesviruses have been implicated in this disease, with conflicting evidence. Case reports suggested a potential association between herpesvirus infection and AIT, but in other report, when thyroid specimens were analysed, no EBV, CMV or HSV-1 DNA is detected. A recent study analyzed the presence of herpesvirus DNA in post-operative thyroid specimens from tissue blocks, and HHV-6 was detected by single round PCR in 2 out of 15 (13.3\%) Hashimoto thyroiditis tissue specimens, whereas in Grave's disease or multi nodular goitre tissues no HHV-6 DNA is detected (Thomas et al., 2008).

In this work significantly ( $\mathrm{p}=0.003$ ) higher rate of HHV-6 and HHV-7 genomic sequence presence in DNA samples extracted from AIT patients thyroid tissue $(43 / 44,98 \%)$ is shown in comparison to the control group (31/41, $76 \%$ ). In 43/44 of AIT patients' thyroid tissue DNA HHV-6 genomic sequence is found. These results show a possible influence of HHV-6 on AIT development. Interesting, that 25/44 (57\%) of patients have HHV-6 genomic presence only in thyroid tissue DNA samples, which evidences on HHV-6 
latency in thyroid glands. However, presence of HHV-6 DNA in lymphocytes infiltrates in tissue could not be excluded. Although, real-time PCR results show that average HHV-6 viral load is higher in tissue DNA samples, rather than in whole blood DNA, which could strengthen the evidence on HHV-6 latency in thyroid gland. These results are advocating to the involvement of HHV-6 infection in AIT development.

The HHV-6B is detected in all DNA samples from patients with HHV-6 infection. This might suggest that either the HHV-6A is infrequent in these patients or it might be limited to sites other than the peripheral blood. Also, one of the causes of dominant HHV-6B presence in patients could be connected with geographical distribution.

This work shows different ways of beta-herpesviruses interaction with the host organism and their involvement in etiopathogenesis of chronic diseases, complication development and clinical course worsening. In renal transplant recipients beta-herpesviruses activity is associated with worsening of immunosuppression during treatment. Also, substantial role in immunosuppression more likely plays also active HHV-7 infection in this group. On the other hand, in patents with GIC lower beta-herpesviruses (HHV-6 and HHV-7) distribution is found than in other two groups of patients - only in $68 \%$ of patients. However, development of lymphopenia in immunocompromised patients with GIC is strongly associated with the active beta-herpesviruses infection. In case of AIT, especially HHV-6 is associated with this disease development (because of its high frequency and higher viral load in thyroid gland tissue in comparison with peripheral blood). HHV-6 and HHV-7 infection, possibly, could be a primary cause, by expressing antigens in thyroid glands during the latent stage of infection or it could play secondary role by infecting and destroying thyrocytes. 


\section{CONCLUSIONS}

1. Renal transplant recipients have higher risk of immunosuppression strengthening and complications development associated with HHV-6 and HHV-7 active infection.

2. Active beta-herpesviruses infection in patients with gastrointestinal cancer is associated with decrease of lymphocytes' total count, increase of IL-6, sIL-2R and decrease of TNF-alpha expression levels leading to the deepening of immunosuppression.

3. HHV-6 and HHV-7 persistent infection is not associated with gastrointestinal cancer stage, at the same time activation of HHV-6 and HHV-7 leads to the worsening of clinical course and outcome of underlying disease.

4. HHV-6 and HHV-7 genomic sequences are frequently detected in thyroid tissue as well as in whole blood DNA samples of patients with autoimmune thyroiditis therefore the association of viral infection with the disease development could not be excluded.

5. Higher viral load in thyroid tissue of autoimmune thyroiditis patients than in whole blood is additional evidence of HHV-6 involvement in this disease development and indicates that thyroid gland is one of the places of HHV-6 latency.

6. HHV-6B is revealed in renal transplant recipients, patients with gastrointestinal cancer and autoimmune thyroiditis, which shows dominant distribution of this species in Latvia. 


\section{RECOMMENDATIONS}

1. Highly sensitive molecular and serological methods are required to detect HHV-6 and HHV-7 infection, which allows distinguishing latent and active phase of persistent infection.

2. HHV-6 and HHV-7 active infection in renal transplant recipients is associated with immunosuppression caused by medication. Therefore, patients with beta-herpesviruses persistent infection should be monitored for the active phase to prevent development of complications in time.

3. In $46 \%$ of patients with GIC association between active betaherpesviruses (HHV-6 and HHV-7) infection and lymphopenia is found. Therefore, patients with beta-herpesviruses persistent infection should be monitored for the active phase to avoid the deepening of lymphopenia in time.

4. Taking into account that thyroid gland is one of the HHV-6 latency places it is recommended to monitor the activity of beta-herpesviruses infection in patients with the first signs of thyroid gland diseases to prevent deepening of the autoimmune process. 


\section{ACKNOWLEDGMENTS}

I would like to express my sincere of gratitude to my supervisors Assoc. Prof. Modra Murovska and Senior Researcher Svetlana Chapenko for invaluable assistance, support and guidance. Also, I would like to express gratitude to Prof. Sandra Lejniece for support and valuable advices.

I would like to express gratitude to Vice-Rector for Science, Prof. Iveta Ozolanta and Scientific Secretary, Ingrida Kreile for support and consultations during doctoral studies.

Finally, I would like to thank all my colleges for moral support. 


\section{THE LIST OF PUBLICATIONS}

\subsection{Publications}

1. Sultanova A., Chistjakovs M., Chapenko S., Donina S., Murovska M. Possible interference of human beta-herpesviruses-6 and -7 in gastrointestinal cancer development // Experimental oncology, 2013; 35 (2): 93-96.

2. Sultanova A., Cistjakovs M., Capenko S., Donina S., Ziedina I., Murovska M. Frequency and activity phase of HHV-6 and HHV-7 persistent infection in renal transplant recipients and patients with gastrointestinal cancer // RSU Research articles in medicine and pharmacy, Collection of Scientific Papers 2013: 54-60.

3. Chapenko S., Ziedina I., Folkmane I., Sultanova A., Rozental R., Murovska M. The impact of beta-herpesviruses infection activation on early complications development following renal transplantation // Current Problems of Infectious Human Pathology, Vol. 4, 2011: 274 278.

4. Gravelsina S., Nora-Krukle Z., Chapenko S., Sultanova A., Boka V., Cunskis E., Murovska M. Incidence of human herpesvirus 6, 7, and parvovirus B 19 infection in patients with thyroid gland disorders // Current Problems of Infectious Human Pathology, Vol. 4, 2011: $283-$ 287.

5. Čistjakovs M., Čapenko S., Sultanova A., Nora Z., Murovska M. Cilvēka sestā herpesvīrusa (HHV-6) tipu sastopamība dažādu personu grupās Latvijā // RSU Zinātniskie raksti 2008 Internā medicīna 
Ķirurǵija Medicīnas bāzes zinātnes Stomatoloǵija Farmācija, 2009, lpp. 317-322.

6. Ziediņa I., Čapenko S., Folkmane I., Sultanova A., Murovska M., Jušinskis J., Rozentāls R. Poliomas-BK vīrusa un beta-herpesvīrusu reaktivācija pēc nieres transplantācijas // RSU Zinātniskie raksti 2008 Internā medicīna Ķirurğija Medicīnas bāzes zinātnes Stomatoloǵija Farmācija, 2009, lpp. 81-84.

7. Муровска М., Чапенко С., Козырева С., Султанова А., Дониня С., Фолкмане И., Круминя А., Лейниеце С., Лейниекс А. Бетагерпесвирусы чеповека (ВГЧ-6, ВГЧ-7), их распространение и ассоциация с патологическими процессами. Материалы Международной научно-практической конференции Вирусные инфекции: эпидемиология, клиника, лабораторная диагностика и профилактика. Минск, Государственное учреждение «НИИ эпидемиологии и микробиологии», 29-30 ноября 2007 г., стр. 9396.

8. Sultanova A., Čapenko S., Nora Z., Doniņa S., Murovska M. Imūnsupresija kā $\beta$-herpesvīrusu aktivācijas faktors pacientiem ar kuņǵa-zarnu trakta onkologíiskām slimībām. Latvijas Universitates raksti. 2007, sēj.: Medicīna, lpp. 20-24.

9. Murovska M., Spuris K., Nora Z., Sultanova A., Čapenko S., Lejnieks A. Limfotropo herpesvīrusu infekcija un vairogdziedzera slimības // RSU Zinātniskie raksti 2003 Internā medicīna Ķirurǵija Medicīnas bāzes zinātnes Stomatologiija Farmācija, 2003, lpp. 389-393. 


\subsection{Abstracts}

1. Sultanova A., Cistjakovs M., Chapenko S., Gravelsina S., NoraKrukle Z., Donina S., Lejniece S., Murovska M. Human herpesvirus 6 and 7 infection as facilitator of chronic diseases and various complications development. $10^{\text {th }}$ International Conference on New Trends in Immunosuppression, Barcelona, Spain, March 11-12, 2013: 196

2. Nora-Krukle Z., Gravelsina S., Chapenko S., Sultanova A., Cunskis E., Murovska M. Association between latent/persistent human herpesvirus 6 (HHV-6) and 7 (HHV-7) infection and diseases of thyroid gland. $8^{\text {th }}$ International Congress on Autoimmunity, Granada, Spain, may 9-13, 2012.

3. Sultanova A., Cistjakovs M., Chapenko S., Donina S., Murovska M. Frequency HHV-6 and HHV-7 infection in patients with different stages of gastrointestinal cancer. $17^{\text {th }}$ International Symposium on Infections in the Immunocompromised Host, Italy, Genova $24^{\text {th }}-27^{\text {th }}$ June, 2012: 65 .

4. Fadeeva I., Sultanova A., Nora-Krukle Z., Murovska M. Human herpesvirus- 6 and -7 resctivation in thyroid gland tissues of patients with thyroid gland disorders., XI International Congress of Medical Sciences, Sofia, Bulgaria, 03-06 May, 2012: 148.

5. Gravelsina S., Nora-Krukle Z., Sultanova A., Chapenko S., Cunskis E., Roga S., Murovska M. Human herpesvirus six and seven and parvovirus B19 infections as possible risk factors for the development of autoimmune and non-autoimmune thyroid diseases. School of 
translational immunology, Belgrade, Serbia, 19-21 September 2012: 45.

6. Nora-Krukle Z., Gravelsina S., Sultanova A., Chapenko S., Rasa S., Roga S., Cunskis E., Murovska M. Prevalence of HHV-6, HHV-7 and parvovirus B19 in thyroid tissue samples from patients with thyroid gland disorders and subjects with unspecified encephalopathies. $22^{\text {nd }}$ Annual Meeting of the Society for Virology, Essen, Germany, March 14-17, 2012: 536.

7. Sultanova A., Chapenko S., Fadejeva I., Gravelsina S., Nora-Krukle Z., Cunskis E., Murovska M. HHV-6 and HHV-7 Infection in Patients with Struma nodosa III. RSU Zinātniskā konference, 2012. gada 29. un 30. martā. Rīgā, lpp. 182.

8. Sultanova A., Chapenko S., Gravelsina S., Nora-Krukle Z., Cunskis E., Murovska M. Genomic sequences of herpesvirus $6 \& 7$ and parvovirus B 19 in DNA samples isolated from thyroid tissues. RSU Zinātniskā konference, 2011. gada 14. un 15. aprīlī., Rīgā, lpp. 225.

9. Sultanova A., Nora-Krukle Z., Chapenko S., Cunskis E., Murovska M. HHV-6 and HHV-7 in patients with thyroid gland disorders. $36^{\text {th }}$ International Herpesvirus Workshop, Gdansk 2011: 8.44

10. Nora-Krukle Z., Sultanova A., Gravelsina S., Chapenko S., Chistyakov M., Cunskis E., Murovska M. Presence and activity of human herpesvirus- 6 and 7 infections in patients with autoimmune thyroid diseases. $7^{\text {th }}$ International Conference on HHV-6\&7, Reston, ASV, 2011: 55.

11. Chistjakovs M., Donina S., Chapenko S., Sultanova A., Murovska M. Immunological parameters in colorectal cancer patients with latent and 
active beta-herpesviruses infection. Acta Chirurgica Latviensis. 5th Baltic Congress of Oncology. 2010: 19.

12. Sultanova A., Chapenko S., Chistjakovs M., Donina S., Murovska M. Influence of HHV-6 and HHV-7 infection on proinflamotory interleukines' levels in colorectal cancer patients before and after surgery. Acta Chirurgica Latviensis. $5^{\text {th }}$ Baltic Congress of Oncology. 2010: 25-26.

13. Ziediņa I., Folkmane I., Čapenko S., Murovska M., Sultanova A., Jušinskis J., Rozentāls R. Poliomas BK vīrusa un beta-herpesvīrusu reaktivācija agrīnā periodā pēc transplantācijas. Rīgas Stradiṇa Universitāte, 2008.gada Zinātniskā konference. Tēzes, 2008: 122.

14. Chapenko S., Donina S., Sultanova A., Jaunalksne I., Kozireva S., Murovska M. Clinical relevance of HHV-6 and HHV-7 infection in gastrointestinal cancer patients at different stages of the disease. International Congress of Virology, 10-16 August 2008, Istanbul. Abstract Book: 396.

15. Čistjakovs M., Čapenko S., Sultanova A., Nora Z., Murovska M. Cilvēka sestā herpesvīrusa (HHV-6) tipu sastopamība dažādu personu grupām Latvijā. RSU Zinātniskā konference, 2008. gada 13. un 14. martā., Rīgā, lpp. 141.

16. Donina S., Chapenko S., Sultanova A., Jaunalksne I., Engele L., Murovska M. Influence of HHV-6 and HHV-7 activation on immunological parameters in colorectal cancer patients. The $35^{\text {th }}$ Meeting of the International Society for Oncodevelopmental Biology and Medicine, ISOBM 2007, September 15-19, 2007, Prague, Czech Republic. Tumor Biology, 2007, 28 (suppl.), p. 121. 
17. Chapenko S., Donina S., Sultanova A., Nora Z., Murovska M. Effect of immunodepression on the activation of beta-herpesviruses in colorectal cancer $(\mathrm{CRC})$ patients. $12^{\text {th }}$ International Congress of Immunology and $4^{\text {th }}$ Annual Conference of FOCIS, 2004, Montréal, Canada. Clinical and Investigative Medicine, 2004, Vol. 27, No 4, p. 150B. 


\section{REFERENCES}

1. Caiola D., Karras A., Flandre P., et al. Confirmation of the low clinical effect of human herpesvirus-6 and -7 infections after renal transplantation // Journal of medical virology, 2012; 84 (3): 450-456.

2. Caselli E., Zatelli M. C., Rizzo R., et al. Virologic and immunologic evidence supporting an association between HHV-6 and Hashimoto's thyroiditis // PLoS pathogens, 2012; 8 (10): e1002951.

3. Chan P. K., Li C. K., Chik K. W., et al. Risk factors and clinical consequences of human herpesvirus 7 infection in paediatric haematopoietic stem cell transplant recipients // Journal of medical virology, 2004; 72 (4): 668-674.

4. Chapenko S., Folkmane I., Ziedina I., et al. Association of HHV-6 and HHV-7 reactivation with the development of chronic allograft nephropathy // Journal of clinical virology : the official publication of the Pan American Society for Clinical Virology, 2009; 46 (1): 29-32.

5. Chapenko S., Folkmane I., Tomsone V., et al. Infection of $\beta$ herpesviruses (CMV, HHV-6, HHV-7): role in postrenal transplantation complication // Transplantation proceedings, 2001; 33 (4): 2463-2464.

6. Csoma E., Mészáros B., Gáll T., et al. Dominance of variant A in human herpesvirus 6 viraemia after renal transplantation // Virology journal, 2011; 8: 403.

7. Grima P., Chiavaroli R., Calabrese P., et al. Severe hepatitis with autoimmune features following a HHV-6: a case report // Cases journal, 2008; 1 (1): 110. 
8. Helantera I., Loginov R., Koskinen P., Lautenschlager I. Demonstration of HHV-6 antigens in biopsies of kidney transplant recipients with cytomegalovirus infection // Transplant international : official journal of the European Society for Organ Transplantation, 2008; 21 (10): 980-984.

9. Holden S. R., Vas A. L. Severe encephalitis in a haematopoietic stem cell transplant recipient caused by reactivation of human herpesvirus 6 and 7 // Journal of clinical virology : the official publication of the Pan American Society for Clinical Virology, 2007; 40 (3): 245-247.

10. Lacroix A., Collot-Teixeira S., Mardivirin L., et al. Involvement of human herpesvirus-6 variant B in classic Hodgkin's lymphoma via DR7 oncoprotein // Clinical cancer research : an official journal of the American Association for Cancer Research, 2010; 16 (19): 47114721.

11. Lempinen M., Halme L., Arola J., et al. HHV-6B is frequently found in the gastrointestinal tract in kidney transplantation patients // Transplant international : official journal of the European Society for Organ Transplantation, 2012; 25 (7): 776-782.

12. Lucas A., McFadden G. Secreted immunomodulatory viral proteins as novel biotherapeutics // The Journal of immunology, 2004; 173 (8): 4765-4774.

13. Mocarski E. S. Jr. Immunomodulation by cytomegaloviruses: manipulative strategies beyond evasion // Trends in microbiology, 2002; 10 (7): 332-339.

14. Ogata M., Satou T., Kawano R., et al. High incidence of cytomegalovirus, human herpesvirus-6, and Epstein-Barr virus 
reactivation in patients receiving cytotoxic chemotherapy for adult $\mathrm{T}$ cell leukemia // Journal of medical virology, 2011; 83 (4): 702-709.

15. Puri R. K., Leland P., Razzaque A. Antigen(s)-specific tumourinfiltrating lymphocytes from tumour induced by human herpes virus6 (HHV-6) DNA transfected NIH 3T3 transformants // Clinical and experimental immunology, 1991; 83 (1): 96-101.

16. Siddon A., Lozovatsky L., Mohamed A., Hudnall S. D. Human herpesvirus 6 positive Reed-Sternberg cells in nodular sclerosis Hodgkin lymphoma // British journal of haematology, 2012; 158 (5): 635-643.

17. Sprengers D., Janssen H. L. Immunomodulatory therapy for chronic hepatitis B virus infection // Fundamental \& clinical pharmacology, 2005; 19 (1): 17-26.

18. Yagasaki H., Kato M., Shimizu N., et al. Autoimmune hemolytic anemia and autoimmune neutropenia in a child with erythroblastopenia of childhood (TEC) caused by human herpesvirus6 (HHV-6) // Annals of hematology, 2011; 90 (7): 851-852.

19. Zawilinska B., Kopec J., Szostek S., et al. Lymphotropic herpesvirus DNA detection in patients with active CMV infection - a possible role in the course of CMV infection after hematopoietic stem cell transplantation // Medical science monitor : international medical journal of experimental and clinical research, 2011; 17 (8): 432-441. 